\title{
PARTNERSTWA ARTYSTYCZNE W POLSKIEJ BRANŻY WYDAWNICZEJ I REKLAMOWEJ PIERWSZEJ POŁOWY XX WIEKU*
}

\begin{abstract}
Fenomen powstawania różnego rodzaju spółek i partnerstw artystycznych w pierwszej połowie XX wieku. Organizacja i typy spółek. Kooperacje artystyczne o charakterze okazjonalnym. Spółki autorskie. Studia i działy graficzne.
\end{abstract}

SŁOWA KLUCZOWE: polska sztuka użytkowa I poł. XX wieku, partnerstwa artystyczne, spółki autorskie, studia graficzne i reklamowe

Polska sztuka użytkowa okresu dwudziestolecia międzywojennego już wielokrotnie przyciągała uwagę badaczy i pasjonatów. Niebywałe tempo i dynamika rozwoju tego obszaru sztuki w odbudowującej się II Rzeczypospolitej były jednymi ze składowych szerzej postrzeganego „renesansu” polskiej kultury, która po latach zaborów miała w końcu szansę, choć na kilka dekad, rozkwitnąć bez żadnych przeszkód. Polską grafikę użytkową lat dwudziestych i trzydziestych zaliczyć można do najciekawszych osiągnięć sztuki europejskiej tego czasu. Popularnymi mediami były plakat, okładka książkowa i czasopiśmienna, aranżacje witryn czy coraz powszechniej stosowane druki ulotne. Działający w tym czasie twórcy czerpali zarówno z najlepszych, często awangardowych, wzorców zagranicznych, jak i podejmowali wielokrotnie próby wypracowania, bardzo różnie postrzeganego, tak zwanego stylu narodowego. I choć taki jednorodny styl nigdy ostatecznie się nie wykrystalizował, to wysiłki w celu jego stworzenia zaowocowały bardzo cie-

* Tematem artykułu jest przede wszystkim zjawisko partnerstwa artystycznego. Słowo „partnerstwo" będzie w związku z tym używane również w liczbie mnogiej, choć słowniki języka polskiego nie odnotowują takiej formy. 
kawymi pracami, zwłaszcza w zakresie wzornictwa i projektowania graficznego. Powstałe w tym czasie plakaty, reklamy, okładki książek i czasopism czy kroje pism do dziś wzbudzają fascynację i nie ustępują poziomem najlepszym światowym osiągnięciom na tych polach.

Zapotrzebowanie na reklamę i inne usługi graficzne generowane przez rozwijające się struktury państwowe i przemysł stworzyło dogodne warunki do rozwoju nowej profesji. Rosnąca rzesza artystów zawodowo zajmujących się sztuką użytkową kształtowała estetykę pokrytych plakatami ulic, sklepowych wystaw czy księgarnianych półek tego okresu, docierając ze swą sztuką do szerokich mas społeczeństwa. Praca artystyczna realizowana w ścisłej zależności od zleceniodawców pociągała za sobą jednak także pewne wyzwania i problemy. Wymagała od twórców sprawności nie tylko plastycznej, ale i biznesowej — pozyskiwania klientów i negocjacji z nimi, organizacji pracy nad wymagającymi szybkiej realizacji projektami czy wreszcie dywersyfikacji umiejętności.

Artyści, zmuszeni sprostać wymaganiom kapitalistycznej rzeczywistości rynkowej, z czasem sami zaczęli wykorzystywać rozwiązania sprawdzone już w innych branżach. Praca na własną rękę, choć najbardziej nieskrępowana, wiązała się dla wielu twórców, zwłaszcza tych młodych, z nieregularnym napływem zleceń oraz innymi problemami, jakie rodzi jednoosobowa działalność. Wraz z rozwojem branży reklamowej i wydawniczej poza „,wolnymi strzelcami” swoje usługi graficzne zaczęły oferować różnego rodzaju mniejsze i większe firmy: studia, atelier i spółki specjalizujące się w różnych gałęziach sztuki użytkowej. Są one ciekawym przykładem zmian, jakie zaszły w sztuce XX wieku pod wpływem rozwoju gospodarczego i postępującej komercjalizacji branży artystycznej.

Artyści, którzy postanawiali poświęcić się pracy w branży wydawniczej i reklamowej, prócz całkiem dobrego zarobku mogli liczyć także na zaprezentowanie swoich prac szerokiemu gronu odbiorców, znacznie wykraczającemu poza dotychczasową grupę zainteresowaną wytworami sztuki wysokiej. Zapewne właśnie ten szeroki zasięg społeczny, możliwy dzięki wykorzystaniu technik masowego zwielokrotniania odbitek graficznych, przyciągał tak wielu utalentowanych twórców. Taki stan rzeczy znajdował zresztą odzwierciedlenie w licznych manifestach i nurtach artystycznych wywodzących się z pozytywizmu, modernizmu czy awangardy, które postulowały niejednokrotnie ściślejszą integrację sztuki z otaczającym ją światem oraz zwracały uwagę na społeczną rolę artysty i jego dzieł.

Komercjalizacja działalności artystycznej obok szerokiego społecznego oddziaływania i masowego zasięgu niosła z sobą także pewne nowe rygory. Wytwory sztuki zaczęły bowiem coraz bardziej podlegać zasadom rynkowym. Sama praca artysty przestała być już tylko jego własnym dziełem — w jego stworzeniu często uczestniczyli w pewnym stopniu klient czy kierownik artystyczny studia, których wymagania i oczekiwania trzeba było spełnić. Sam projekt artystyczny 
podlegał również pewnym przekształceniom w procesie technologicznym związanym z wykonaniem form i odbitek. Nieskrepowana ekspresja artystyczna musiała ustąpić pola celom nadrzędnym — zadowoleniu klienta i przede wszystkim trafieniu w gusta docelowego odbiorcy.

Ingerencja $\mathrm{w}$ artystyczną autonomię $\mathrm{i}$ integralność dzieła sięgała niekiedy jeszcze dalej. Krytyczne uwagi kierownictwa studia czy bardziej doświadczonego twórcy, mogące znaleźć zastosowanie jeszcze w trakcie samego powstawania projektu, z pewnością przyczyniały się do poprawy jakości prac. Niejednokrotnie zdarzało się również, że same prace były wręcz współtworzone rękami kilkorga projektantów. Stały za tym przede wszystkim względy praktyczne — wysokie tempo pracy i wszechstronne umiejętności, jakich wymagała zwłaszcza branża reklamowa, sprzyjały rozwinięciu się kooperacyjnego modelu pracy kreatywnej. Takie połączenie talentów i temperamentów artystycznych nierzadko dawało doskonałe efekty.

Fenomen częstego powstawania różnego rodzaju spółek autorskich i studiów graficznych w międzywojniu był już niejednokrotnie przedmiotem zainteresowania badaczy. Na ich ważny wkład w projektowanie graficzne okresu międzywojennego bodaj najwcześniej uwagę zwróciła Maria Łącka. Na marginesie swego opracowania poświęconego Kołu Artystów Grafików Reklamowych sygnalizowała istotną rolę spółek autorskich wśród twórców przedwojennej grafiki użytkowej (1963). Jej postulat bardziej szczegółowego zbadania tego zjawiska nie spotkał się dotychczas z odzewem, choć wątek ten pojawiał się pośrednio w kilku pracach, między innymi u Piotra Rypsona (1992, 2017) czy Szymona Bojki (1971). Dostępnych jest coraz więcej opracowań biograficznych dotyczących poszczególnych artystów tego okresu, także tych tworzących w ramach spółek (Kaczorowski, 2017; Warda, 2017). Cennym źródłem jest biografia Anatola Girsa autorstwa A. Kłossowskiego (1989). Monografii w postaci dysertacji naukowych doczekały się również Atelier Mewa (Chmielewska, 1993) oraz Studio Levitt-Him (Kaczorowski, 2020). Grafikom z kręgu absolwentów Wydziału Architektury Politechniki Warszawskiej i zawiązywanym przez nich podmiotom partnerskim przyglądały się z kolei Dorota Parszewska (2005) i Magdalena Zdrenka (2013d). Ta ostatnia przygotowała także cykl artykułów poświęconych najważniejszym duetom i studiom graficznym przedwojennej Polski: spółkom Girs-Barcz, Levitt-Him, Franciszkowi i Annie Seifertom, Atelier Mewa, Atelier Plakat oraz biuru Reklama-Mechano (Zdrenka, 2012, 2013a, 2013b, 2013c, 2013e, 2014). Artystyczne tandemy przyciągały także niekiedy uwagę ówczesnych krytyków, a opublikowane przy tej okazji artykuły stanowią dziś cenne źródło informacji na temat działania tych spółek (Hölscher, 1936; Smolik, 1935a, 1935b, 1935c). Niekiedy informacje o tego typu kooperacjach podejmowanych przez poszczególnych twórców pojawiają się w notach biograficznych, zwłaszcza na łamach poważnych opracowań informa- 
cyjnych $^{1}$. Nie zostały jednak jak do tej pory podjęte próby bardziej syntetycznego omówienia tego fenomenu, jego skali, źródeł ani oddziaływania.

Przy obecnym stanie wiedzy o przedwojennej sztuce użytkowej i jej twórcach oraz dzięki dostępowi do ich prac, coraz częściej również w postaci zdigitalizowanej, dziś możliwe jest przygotowanie choćby przybliżonego zarysu tego zjawiska. Podstawą niniejszego wywodu były szeroko zakrojone poszukiwania informacji źródłowych oraz wytworów sztuki użytkowej świadczących o kolektywnej pracy artystycznej. Starano się ustalić przede wszystkim możliwie pełną listę tandemów, spółek autorskich, studiów graficznych i atelier reklamowych, które odpowiadały bezpośrednio za tworzenie projektów graficznych rozmaitych druków tego okresu.

Dla znalezionych w trakcie tych poszukiwań spółek próbowano ustalić czas i miejsce ich działalności, nazwiska wchodzących w ich skład artystów, stopień formalizacji i wewnętrznej hierarchii, a także główne pola działalności. Na podstawie tych informacji możliwe stało się stworzenie podziału na trzy podstawowe typy spółek artystycznych, jakie występowały w przedwojennej Polsce. Jak zobaczymy w dalszej części tekstu, różnice między nimi są dość istotne, a dotychczasowe dość ogólne traktowanie ich działalności wydaje się mało precyzyjne.

Zanim jednak przedstawione zostaną szczegółowo trzy wspomniane rodzaje artystycznych kooperacji oraz ich specyfika, warto nieco uwagi poświęcić genezie zjawiska współpracy artystycznej na polu grafiki użytkowej. Należy zastanowić się, jakie uwarunkowania wpłynęły na wykształcenie się modelu artystycznej pracy zespołowej w opozycji do twórczości indywidualnej.

Pośrednich przyczyn rozwinięcia się sposobu pracy nad dziełem z udziałem więcej niż jednego twórcy można się dopatrywać w rewolucji przemysłowej, towarzyszącemu jej rozwojowi gospodarczemu i umasowieniu produkcji. Czynniki te wykształciły zapotrzebowanie na usługi artystyczne w nowych, wcześniej nieobecnych bądź marginalizowanych, obszarach. Sprawne zaspokajanie rosnących potrzeb na coraz bardziej skomercjalizowanym rynku sztuki wymuszało na twórcach szukanie nowych dróg działania, pozwalających na zwiększenie jakości i efektywności pracy artystycznej, która coraz bardziej zaczęła podlegać prawom ekonomii. Warto jednak zastanowić się, w którym momencie artyści związani ze sztuką użytkową musieli przewartościować model działania, w którym centralną rolę twórcy i dzieła zastąpiły idea kooperacji i praca będąca wynikiem konsensusu.

Początków grupowej praktyki twórczej można się dopatrywać już w czasach, kiedy wielcy mistrzowie stali na czele sprawnie działających pracowni malarskich, w których młodzi, często anonimowi artyści „produkowali” prace pod

${ }^{1}$ Najbardziej przydatne okazały się: Polski Stownik Biograficzny; Stownik artystów plastyków: artyści plastycy Okręgu Warszawskiego ZPAP, Warszawa 1972 oraz Słownik artystów polskich i obcych w Polsce działajacych: malarze, rzeźbiarze, graficy, t. 1-10, red. Jolanta Maurin-Białostocka et al., Wrocław-Warszawa 1975-2016. 
czujnym okiem swoich pracodawców i nauczycieli. Zjawisko kooperacji, będącej przedmiotem niniejszej analizy, ma jednak inne źródła, a związki tak odległe wydają się dość mgliste, biorąc pod uwagę rozległe zmiany społeczne, polityczne i gospodarcze, których doświadczyła zachodnia cywilizacja wraz z wejściem w wiek najpierw pary, a później elektryczności.

Analizowany tutaj typ kooperacyjnej pracy artystycznej można zapewne bezpośrednio wywodzić od studiów działających jako przybudówki dużych zakładów graficznych, drukarń czy biur ogłoszeń, które w okresie międzywojnia i wcześniej odgrywały ważną rolę w pośrednictwie między zleceniodawcami a wykonawcami, szczególnie w przypadku projektów reklamowych. Drukarnie już od dekad oferowały swym klientom usługi polegające na projektowaniu druków (biletów, afiszy, prospektów itp.), jednak ograniczały się zazwyczaj do prac typograficznych, wzbogaconych ewentualnie o standardowe ornamenty czy sztampowe winiety pochodzące z zasobów zakładu. Wzrost konkurencji i dynamiczny rozwój metod reklamy, będące konsekwencją postępującego umasowienia produkcji, wpłynęły na rosnące zapotrzebowanie na projekty graficzne. Ich tworzenie wymagało udziału zdolnych i sprawnych manualnie artystów plastyków. Aby odpowiedzieć na to zapotrzebowanie, działające przy zakładach graficznych studia zaczęły prócz wykwalifikowanych typografów zatrudniać również grafików i fotografików, którzy byli w stanie zapewnić projektowanym drukom nowoczesną i efektowną formę. Agencje reklamowe, mające zazwyczaj bezpośredni kontakt ze zleceniodawcą, również zaczęły angażować do wykonania bardziej ambitnych projektów niezależnie działających artystów. Z czasem niektóre z nich, dostrzegając obiecującą niszę, zaczęły rozwijać w ramach własnych struktur przyzakładowe studia i pracownie graficzne. Posunięcie takie zakładało zapewne obniżenie kosztów wykonania projektów oraz skrócenie czasu ich dostarczenia i przygotowania do druku.

Działające w ten sposób studia-przybudówki dawały zatrudnionym w nich artystom stały napływ zleceń oraz stałość zatrudnienia. Taka forma pracy skazywała jednak twórców na przywiązanie do jednego podmiotu, w ramach którego ich autonomia była z reguły ograniczona. Duże tempo pracy prowadzące do sztampy, brak wpływu na repertuar zleceń oraz uwikłanie w zależności wewnątrz firm zapewne zniechęcały wiele osób do tej formy działalności artystycznej. Dodatkowo anonimowość dzieł wykonywanych w takich spółkach uniemożliwiała utalentowanym artystom kreowanie własnej marki i zaistnienie na rynku sztuki użytkowej. Twórcy przystępujący do pracy w takich studiach graficznych zmuszeni byli także do zaakceptowania parakorporacyjnego trybu pracy. Realizując projekty, często musieli trzymać się szczegółowych wytycznych klienta i oczekiwań pracodawcy, który mógł bezpardonowo ingerować w ich twórczą działalność. 
Mimo przedstawionych słabości i niedogodności taki model funkcjonowania wykształcił u projektantów świadomość możliwości kooperacyjnej czy nawet korporacyjnej pracy artystycznej. Świadczyło to o wzroście znaczenia sztuki użytkowej i okrzepnięciu idei sztuki komercyjnej, podporządkowanej rosnącym potrzebom przemysłu, rynku usług i mediów masowych. Wzrost roli reklamy oraz rozwój poligrafii przyczyniły się do powstania niszy, którą wypełnić mogła nowa profesja artystów komercyjnych, dziś zwanych designerami. Rynkiem sztuki użytkowej zaczęły z czasem w coraz większym stopniu rządzić te same prawa, co każdym innym obszarem kształtowanym przez mechanizm popytu i podaży. Rosnące zapotrzebowanie na usługi graficzne przyciągało coraz liczniejszych absolwentów uczelni artystycznych i wydziałów architektury. Praca projektanta nie była już dla nich tylko dodatkowym zajęciem, lecz często podstawowym źródłem utrzymania.

W pierwszych dekadach XX wieku obok działających na własną rękę ,,wolnych strzelców”, współpracujących z różnego rodzaju zakładami graficznymi, agencjami reklamowymi czy bezpośrednio z działami reklamy dużych przedsiębiorstw, istniały także zorganizowane studia graficzne. Były to samodzielne firmy, świadczące zainteresowanym klientom usługi graficzne, często też stanowiły przybudówki przedsiębiorstw, które zajmowały się innego rodzaju działalnością - drukarską lub ogłoszeniowo-reklamową.

Usprawnienie procesu twórczego oraz zwiększenie efektywności pracy, które były w stanie zaoferować dobrze zorganizowane studia graficzne, nie uszło zapewne uwadze tak klientów, jak i samych artystów, którzy z pewnością dostrzegali korzyści płynące zarówno z zespołowej pracy koncepcyjnej, jak i łączenia swych talentów i umiejętności w ramach wspólnej pracy nad projektami. Działalność w spółce pozwalała także ograniczać koszty, jakie generował na przykład wynajem studia. Już wcześniej wielu twórców, także pracujących niezależnie, dzieliło w tym czasie pracownie z kolegami z branży. Był to z pewnością kolejny czynnik sprzyjający zawieraniu nowych znajomości i zacieśnianiu więzów środowiskowych.

Od połowy lat dwudziestych, a nawet wcześniej, obserwować można początki tendencji do podejmowania przez artystów krótkotrwałej współpracy — często na rzecz wykonania jednego lub kilku dzieł. W efekcie działalności artystycznych tandemów (a czasem większych grup) powstawało wiele doskonałych prac, zwłaszcza plakatowych. Dzięki współdziałaniu partnerzy mogli zwiększać potencjał koncepcyjny, a także uzupełniać nawzajem swoje słabe strony. W ramach duetu mogli na przykład twórczo dopełniać się uzdolniony liternik z artystą lepszym w sferze malarskiej czy doskonały rysownik z kolegą bieglej operującym barwą. Artyści mniej sprawni warsztatowo, dysponujący jednak dobrymi pomysłami, mogli zaistnieć niekiedy dzięki współpracy z osobami o większych zdolnościach manualnych. Partnerstwa takie mogły mieć również inne podłoże - umożliwiały łączenie dobrych organizatorów i biznesmenów, będących w stanie pozyskać 
i utrzymać grono klientów, z partnerami mniej zaradnymi, ale za to doskonałymi warsztatowo. Łatwo wyobrazić sobie korzyści płynące z takiego związku dla obydwu stron.

Zapewne na bazie doświadczeń zebranych przy okazji tych epizodycznych partnerstw oraz pracy w komercyjnych studiach graficznych mniej więcej na początku lat trzydziestych wykształcił się kolejny model kooperacyjnej działalności artystycznej. Stanowił on nową alternatywę dla pracy solowej i jednocześnie był pewnym rozwinięciem bardzo już popularnych w tym czasie krótkotrwałych partnerstw między artystami. Na rynku sztuki użytkowej pojawiły się firmy nowego rodzaju - spółki autorskie. Były to zawiązywane przez dwóch, czasem trzech, artystów studia graficzne, których trzon stanowili właśnie partnerzy-założyciele. Spółki takie, choć działające na nieco mniejszą skalę, efektywnością pracy i sprawnością organizacyjną były w stanie konkurować nawet z dużymi graczami branży graficznej. Taka forma działalności dawała też inne korzyści - zwiększona, zespołowa wydajność przekładała się z pewnością na lepsze zarobki, których całość dzielona była pomiędzy partnerów. Warto bowiem wspomnieć, że praca najemna w dużych studiach graficznych częstokroć nie była finansowo satysfakcjonująca dla zatrudnianych w nich artystów. Dochody z realizowanych zleceń musiały sfinansować zaplecze kadrowe i techniczne oraz zaspokoić oczekiwania właścicieli, do których trafiała większa część zysku. Można więc rozpatrywać powstawanie spółek autorskich jako podejmowaną przez artystów próbę ograniczania rosnących wpływów dużych firm i zaznaczenia swojej niezależności jako autonomicznych podmiotów w branży reklamowo-propagandowej.

Koniec lat dwudziestych i lata trzydzieste były czasem, gdy profesja artysty komercyjnego okrzepła, a obszar jego działania stał się akceptowaną i rozwojową branżą, przyciągającą wielu utalentowanych twórców. Oprócz wspomnianych spółek i studiów o charakterze komercyjnym zaczęły w Polsce powstawać także zrzeszenia skupiające osoby pracujące $w$ branży grafiki użytkowej. Pierwszym takim stowarzyszeniem, którego celem było promowanie wysokich standardów oraz reprezentowanie interesów pracowników reklamy, był powstały w 1928 roku Polski Związek Reklamowy (dalej: PZR). Jego prezesem został dawny dyrektor Polskiej Agencji Telegraficznej Piotr Górecki, a w poczet członków zaproszono również przedstawicieli środowisk drukarskich (Kazimierz Główczewski) oraz artystycznych (Stefan Norblin, później Tadeusz Gronowski). PZR szybko zaczął odgrywać rolę pośrednika w kontaktach twórców sztuki użytkowej z przedstawicielami najważniejszych państwowych instytucji i przedsiębiorstw zainteresowanych działalnością propagandową.

Kolejnym sygnałem świadczącym o ukonstytuowaniu się zawodu grafika reklamowego oraz wyraźnej integracji jego przedstawicieli jest założenie w 1933 roku Koła Artystów Grafików Reklamowych (dalej: KAGR). Zostało ono powołane do 
życia z inicjatywy Edmunda Bartłomiejczyka, a wśród członków-założycieli znaleźli się wybitni przedstawiciele grafiki użytkowej tego okresu: Stanisław Ostoja-Chrostowski, Henryk Nowina Czerny, Ludwik Gardowski, Zygmunt Glinicki, Tadeusz Gronowski, Edmund John, Jan Emil Mucharski, Adam Półtawski, Henryk Stażewski, Józef Tom i Jerzy Zaruba. Koło, któremu patronował PZR, jako że skupiało praktyków sztuki użytkowej, szybko stało się wykonawczym ramieniem Związku, który w tym czasie blisko współpracował również z Polskim Związkiem Wydawców Dzienników i Czasopism (Rudziński, 1974). Dzięki siatce powiązań ówczesnych działaczy branży reklamowej ze światem polityki i przemysłu przez KAGR przechodziło wiele atrakcyjnych zleceń, których wykonanie powierzano coraz liczniejszemu gronu członków Koła.

Koło, a przede wszystkim skupieni w jego kręgu artyści, odegrało ważną rolę w kształtowaniu estetyki druków reklamowych, użytkowych oraz wydawnictw prasowych i książkowych tego czasu. Jego działalność, którą szczegółowo opisała M. Łącka, miała jednak wymiar nie tylko praktyczny czy komercyjny. KAGR z pewnością integrowało środowisko warszawskich grafików reklamowych oraz wprowadzało między nich ducha zdrowej rywalizacji, sprzyjającej utrzymaniu wysokich standardów pracy. Zacieśniały się także więzy między kolegami i rodziły się nowe znajomości, które oprócz rozbudowy branżowych kontaktów mogły skutkować ciekawymi wspólnymi przedsięwzięciami artystycznymi.

Można uznać, że trend zawiązywania różnego rodzaju spółek, tandemów i grup partnerskich świadczących usługi graficzne jest zjawiskiem, które kojarzyć można $\mathrm{z}$ rozwojem i umacnianiem się w przedwojennej sztuce nurtu modernistycznego. Łączy się to zarówno z postępującym w tym czasie samookreśleniem zawodu artysty komercyjnego, jak i powstawaniem ośrodków kształcących w duchu funkcjonalizmu. Duży wpływ na upowszechnienie projektowania zespołowego miały środowiska architektów, którzy bodaj najwcześniej zaczęli doceniać korzyści płynące z pracy kolektywnej. Architektura modernizmu, stawiająca na kompleksowość, integralność i funkcjonalność, wymagała często wszechstronnej wiedzy i różnorodnych umiejętności, które rzadko mógł zaspokoić jeden projektant.

Zinstytucjonalizowane kształcenie w zakresie sztuk użytkowych z pewnością także przyczyniło się do upowszechnienia idei kooperacyjności. Wymiana myśli i umiejętności na poziomie akademickim, praca grupowa, budowanie relacji między mistrzami i uczniami czy duch współzawodnictwa to tylko niektóre ze składowych tego procesu. Szkoły takie jak niemiecki Bauhaus, rosyjski Wchutiemas czy polski Wydział Architektury Politechniki Warszawskiej wypuszczały na rynek świetnie przygotowanych młodych architektów, grafików, typografów i projektantów innych specjalności. Postulowane przez modernistów podporządkowanie sztuki celom społecznym, funkcjonalnym czy praktycznym wymagało $\mathrm{z}$ jednej strony ograniczenia twórczej inwencji artysty, z drugiej natomiast wy- 
korzystywania umiejętności często wykraczających poza możliwości nawet najbardziej uzdolnionych jednostek. Powstawały wówczas śmiałe, monumentalne koncepcje urbanistyczne czy kompleksowe, totalne w swym założeniu projekty architektoniczne, zakładające udział projektanta od szkicu bryły po wykonanie najdrobniejszych detali wnętrza. Realizacja przedsięwzięć o tak dużym poziomie skomplikowania wymuszała wręcz pracę zespołową. Model działalności kooperacyjnej szybko znalazł jednak zastosowanie również przy projektach mniej spektakularnych, choć równie ważnych. Kształceni w duchu modernizmu projektanci dostrzegali korzyści płynące ze współpracy nie tylko z przedstawicielami własnej dyscypliny. Jako przykład posłużyć może tandem socjologa Otto Neuratha i grafika Gerda Arntza, którzy zasłynęli dzięki świetnym rozwiązaniom w zakresie wizualizacji informacji i danych z wykorzystaniem diagramów i piktogramów.

Awangardowe nurty w chęci zjednoczenia sztuki z rzeczywistością i formy z treścią posuwały się jeszcze dalej. Głośnym echem odbiły się, mimo niewielkich nakładów, projekty druków czerpiących z funkcjonalizmu, koncepcji nowej typografii, konstruktywizmu i innych nowoczesnych nurtów. Choć poezja wizualna znana była od wieków, dopiero lata dwudzieste i trzydzieste przyniosły próby pełnego zjednoczenia formy materialnej $\mathrm{z}$ warstwą komunikatu $\mathrm{w}$ celu uzyskania nowej jakości. Eksperymenty literacko-typograficzne i graficzne podejmowali sami poeci i literaci, jak Tytus Czyżewski, Anatol Stern czy Stanisław Młodożeniec, którzy projektowali okładki, a nawet układy własnych tomików. Warto wspomnieć również o innych kooperacjach zawiązywanych w tym czasie na polu poezji i literatury, między innymi twórczość A. Sterna i Aleksandra Wata dla almanachu futurystycznego $G G A$. Poeci awangardowi, przywiązujący dużą wagę do wizualnej postaci swych wierszy, chętnie wchodzili we współpracę z plastykami. Najbardziej znana jest wspólna praca Sterna i Mieczysława Szczuki — autorów i zarazem projektantów poematu Europa z okładką przygotowaną później przez Teresę Żarnowerównę. Wiadomo, że z poetami blisko współpracował także Władysław Strzemiński, który projektował oryginalne układy i okładki dla Juliana Przybosia czy Jana Brzękowskiego. Innym przykładem może być tomik Barwy Stanisława Jerzego Leca z okładką Ottona Hahna i funkcjonalistycznym układem graficznym Pawła Hechta. Takie kompleksowe podejście do projektowania, w którym tekst jest starannie skomponowany i spasowany z układem graficznym, rozwijał w swym studiu reklamowym także Henryk Berlewi wraz z partnerami-literatami - Stanisławem Bruczem i A. Watem. Obok firmy reklamowej prowadzili oni również przez krótki czas wydawnictwo Jazz, które jednak, zapewne ze względu na awangardową stylistykę publikacji, nie znalazło wielu odbiorców. Oryginalny tandem plastyczno-literacki tworzyli złączeni więzami małżeńskimi Franciszka i Stefan Themersonowie, działający na rozmaitych polach sztuki, często przy tym wzajemnie się uzupełniając. 
Na przełomie lat dwudziestych i trzydziestych branża skupiająca twórców sztuki użytkowej była już dojrzała, o czym świadczy zawiązywanie się stowarzyszeń zawodowych i organizacja kształcenia w tym zakresie. Artyści, pracujący zawodowo nad budowaniem cudzego wizerunku za pośrednictwem komunikatów wizualnych, z pewnością bardzo wcześnie dostrzegli potrzebę tworzenia także własnej marki. Przynależność do ciała takiego jak KAGR z pewnością była atutem w oczach potencjalnych klientów, jednak nic nie świadczy o twórcy tak jak jego prace. Zapewne dlatego dzieła przedwojennej polskiej sztuki użytkowej — plakaty, okładki, a nawet druki reklamowe - były częstokroć sygnowane. Sygnatury te w przypadku niektórych spółek czy studiów graficznych zamieniały się wręcz w charakterystyczny firmowy znak, który był częścią przemyślanej strategii wizerunkowej. Takie oryginalne „sygnety” graficzne stosowały między innymi Girs i Barcz, Atelier Mewa, Plakat, Ara czy Ruch. Często właśnie dzięki sygnaturom na poszczególnych pracach można dziś badać dorobek poszczególnych twórców, a także uzyskać informacje o rodzajach partnerstw, w jakie ci wchodzili. Otwarte jest dziś pytanie, czy sama zamiana indywidualnej działalności o charakterze „freelancerskim" na bardziej zorganizowane i będące podmiotem gospodarczym studio, spółkę autorską czy nawet jednoosobowe atelier także nie miała wydźwięku wizerunkowego. Spółka to już przecież firma, a to może wzbudzać zaufanie i dawać pewne poczucie solidności. O motywacjach, które skłaniały poszczególnych twórców do wchodzenia w różnego rodzaju układy partnerskie, nie mamy dziś wiarygodnych informacji. Aby jednak precyzyjniej zbadać opisywane zjawisko, warto bardziej szczegółowo przyjrzeć się trzem wspomnianym typom podmiotów organizacyjnych, jakie wyłaniają się z analizy różnorodnego zbioru firm i tandemów artystycznych działających w okresie dwudziestolecia międzywojennego.

Niniejszy przegląd obejmuje trzy odmienne typy kooperacyjnego partnerstwa artystycznego na polu sztuki użytkowej: krótkotrwałe partnerstwa epizodyczne, długoterminowe spółki autorskie oraz działające na kształt niewielkich przedsiębiorstw studia graficzne. Być może z uwagi na nazewniczy galimatias oraz skąpe informacje na temat ich działalności te trzy rodzaje podmiotów często bywają traktowane jako pewna zwarta grupa mimo istotnych różnic, jakie można między nimi wskazać. Pierwszą z nich jest czas ich trwania — podczas gdy partnerstwa epizodyczne obejmowały wykonanie jednego, ewentualnie kilku projektów, spółki autorskie oraz studia graficzne były nastawione na działanie długotrwałe i budowanie firmowej marki. Wytwarzane przez nie prace często można liczyć w setkach czy tysiącach, a najbardziej uznane działały z powodzeniem przez wiele lat.

Różny był także stopień formalizacji tych spółek — co prawda niewiele wiadomo na temat prawnych ustaleń między większością współpracujących z sobą artystów, jednak można zakładać, że w przypadku krótkotrwałych, okazjonalnie zawieranych kooperatyw podstawą ich funkcjonowania była dżentelmeńska umowa. 
SOATELIER GIRS-BARCZ

ace

2

meva 1935

\section{SATELIER RUCH}

T.RRYSXAK
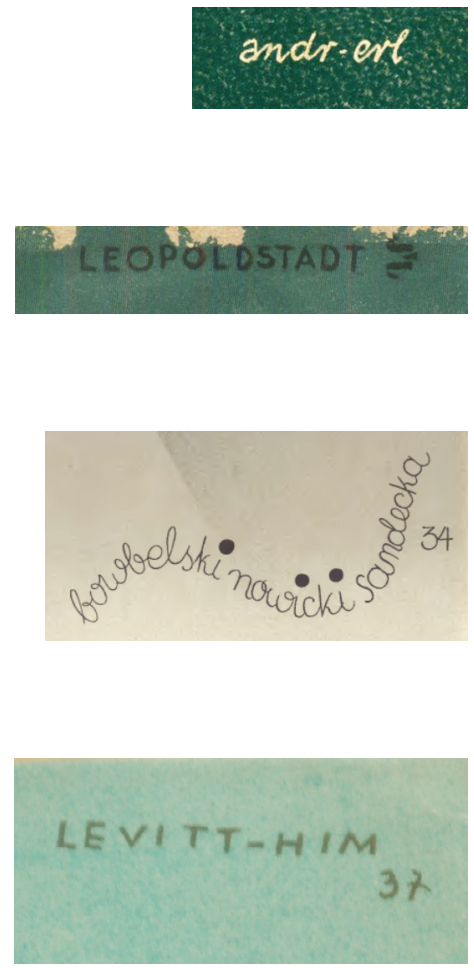

Sygnatury studia Levitt-Him, po wyjeździe do Wielkiej Brytanii działającego jako Lewitt-Him
Jeden z wariantów sygnatury i znaku Atelier Girs-Barcz

Jeden z wariantów sygnatury i znaku Atelier Mewa

Znak Atelier Ruch (wariant z sygnaturą T. Kryszaka)

Sygnatura duetu Rubinrot-Lipiński

Jeden z wariantów sygnatury Atelier Leopoldstadt

Wspólna sygnatura A. Bowbelskiego, M. Nowickiego i S. Sandeckiej

\section{LEWITT-HIM}


Studia graficzne, a z dużym prawdopodobieństwem także spółki autorskie, działały natomiast w sposób bardziej sformalizowany, często jako zarejestrowane firmy. Te pierwsze, jak wspomniano już wcześniej, bywały przybudówkami dużych przedsiębiorstw poligraficznych czy ogłoszeniowych, zarówno prywatnych, jak i państwowych.

Stopień formalizacji oraz rodzaj współpracy wymuszał także wewnętrzną strukturę i hierarchię. Spółki autorskie oraz epizodyczne współprace bazowały zapewne na partnerskiej relacji między zaangażowanymi w nie artystami. Można zakładać, że najczęściej konsekwencją tego układu były równy podział zysków i jednakowy status w ramach spółki. W odniesieniu do studiów graficznych, których struktura organizacyjna była często bardziej rozbudowana, sytuacja jest skomplikowana. Ich właściciele - niekiedy osoby jedynie pośrednio związane $\mathrm{z}$ branżą - często powierzali kierownictwo artystyczne studiów czołowym twórcom tego okresu. To oni nadzorowali pracę zatrudnionych tam artystów lub zapraszali do współpracy nad projektami zewnętrznych wykonawców. Obok nich przedsiębiorstwa takie często zatrudniały również personel pomocniczy (kopistów, fotografików przygotowujących klisze i formy) oraz administracyjny (pracowników sekretariatu, księgowości itp.). Stosunki wewnątrz tego typu spółek miały zgoła inny charakter, który opisać można jako relację szef-pracownik. Podczas gdy skład mniejszych spółek partnerskich był z reguły ustalony i niezmienny od ich założenia aż do rozwiązania, duże podmioty charakteryzowały się większą rotacją pracowników i częstymi zmianami kadrowymi. Zdarzało się, że niektórzy artyści pracowali kolejno, a nawet równolegle, w kilku studiach. Ikony przedwojennego projektowania, takie jak T. Gronowski, Kazimierz Mann czy J.E. Mucharski, na marginesie własnej działalności artystycznej często pomagały w organizacji poważnych studiów graficznych działających przy zakładach drukarskich o ugruntowanej pozycji. Młodzi artyści z kolei często debiutowali w tych studiach, zyskując w ten sposób pierwsze doświadczenia na rynku sztuki użytkowej. Tak było między innymi w przypadku słynnych w latach późniejszych A. Girsa (Atelier Plakat) czy związanych z Atelier Grafik Leona Chejfeca i Jana Levitta.

Można zaobserwować zresztą, że artyści mający wcześniejsze doświadczenia w pracy w ramach studiów graficznych często odważnie podchodzili także do sprawy partnerstwa artystycznego - Levitt współpracował później krótko z Chejfecem i Juliuszem Krajewskim, by ostatecznie stworzyć wieloletnią spółkę z Jerzym Himem; Girs z kolei był blisko związany z Bolesławem Barczem. Oprócz tych dwóch najbardziej znanych tandemów artystycznych przedwojennej Warszawy podobnych przykładów można znaleźć więcej.

Chyba najciekawszym, ale zarazem jednak najtrudniejszym do zrekonstruowania z uwagi na małą liczbę źródeł, zagadnieniem jest sposób wewnętrznej organizacji spółek. Szczątkowe informacje, jakie wyłaniają się z zachowanych 
materiałów biograficznych poszczególnych twórców, wskazują, że zarówno charakter samych spółek, jak i relacje łączące poszczególnych artystów mogły się od siebie bardzo różnić, a także zmieniać w czasie. W dużych studiach stosunki między zatrudnionymi artystami a kierownictwem przypominały pracę czeladników i mistrzów w warsztatach rzemieślniczych. Z kolei spółki zawiązywane między artystami oparte były na relacjach koleżeńskich i partnerskich, choć nie wykluczało to pewnych tarć podczas długotrwałej współpracy (choć zapewne działo się tak również przy krótkotrwałej kooperacji). Warto również zastanowić się, jak w praktyce wyglądało takie współdziałanie artystyczne. Czy ograniczało się do wspólnej pracy koncepcyjnej i krytycznej oceny pracy partnera czy podwładnego? Czy może sięgało dalej - włącznie z ingerencją w dzieło cudzego autorstwa, skorygowanie jego kształtu, dodanie własnych elementów, dobór koloru? Kwestie te w przypadku większości spółek pozostają dziś nieznane. Jak zresztą wskazuje przykład spółki Levitt-Him, sami artyści niekiedy z premedytacją zachowywali szczegóły współpracy w sekrecie. Ze szczątkowych informacji na ten temat, dostępnych w źródłach biograficznych, między innymi dotyczących wspomnianych już wcześniej tandemów, wnioskować można, że nie warto doszukiwać się w tym zakresie reguły. Stopień bliskości współpracy mógł zmieniać się na przestrzeni lat oraz być zależny od poszczególnych projektów, bowiem niektóre dzieła sygnowane firmowym znakiem są w istocie pracami jednego twórcy. Zlecenia poważniejsze, bardziej złożone koncepcyjnie czy angażujące różnorodne umiejętności partnerów, z kolei często zmuszały ich do ścisłej kooperacji, zarówno w sferze koncepcyjnej, jak i warsztatowej. Przykłady najlepiej dziś zbadanych atelier graficznych — Levitt-Him i Girs-Barcz — wskazują, że artyści w ramach współpracy szybko uczyli się uzupełniać swe braki atutami partnera. Wygadany i nieugięty w negocjacjach Levitt tworzył doskonały duet z raczej wycofanym i nieśmiałym Himem, a wszechstronnie wykształcony i zaznajomiony z nowinkami technicznymi Him dobrze uzupełniał braki partnera, który był samoukiem. Literniczy talent Levitta wykorzystywany był z kolei w wielu pracach okładkowych i reklamowych, wymagających ciekawej aranżacji tytułu czy sloganu reklamowego. U Girsa i Barcza temu pierwszemu przypadało dbanie o klientów, bo drugi z reguły jedynie ich odstraszał. Girs pomógł również Barczowi opanować tajniki technik graficznych, w których ten — jako malarz i rzeźbiarz — nie był zbyt biegły. Na podstawie tych dwóch przykładów dostrzec można, jak złożone były relacje w podobnych spółkach i do jak ciekawych artystycznych efektów doprowadzać mogły takie zderzenia talentów, umiejętności, temperamentów i artystycznej wrażliwości.

$\mathrm{Z}$ zestawienia starano się wyeliminować firmy, które, choć ich nazwa mogła to sugerować, nie prowadziły samodzielnej działalności graficznej. W Warszawie oraz innych dużych ośrodkach miejskich działało w tym czasie wiele agencji re- 
klamowych pełniących jedynie rolę biur ogłoszeń. Udostępniały one powierzchnie reklamowe, pośredniczyły w sprzedaży inseratów prasowych i organizowały rozmaite działania reklamowe. Choć z czasem zaczęły one coraz częściej korzystać z usług grafików, ich domeną nie była sztuka reklamowa. Jedynie nieliczne $\mathrm{z}$ nich inwestowały w stworzenie samodzielnych działów graficznych. Pod nazwą atelier, pracowni czy studiów funkcjonowało także wiele firm zajmujących się fotografią, wytwarzaniem neonów, szyldów czy dekoracją wnętrz. Starano się wykluczyć je z niniejszego wykazu, w którym zebrano jedynie partnerstwa, spółki i studia bezpośrednio zaangażowane w tworzenie grafiki użytkowej o zasięgu masowym, przede wszystkim na potrzeby propagandy i reklamy oraz prasy i wydawnictw książkowych.

Nie zostały ujęte również rozmaite współprace plastyków z przedstawicielami innych dziedzin sztuki, które stanowią osobne zjawisko. Na gruncie krajowym inicjatywy te łączyć można przede wszystkim z radykalnymi tendencjami funkcjonalistycznymi, które postulowały coraz mocniejszą integrację treści i formy druków. Ciekawym problemem badawczym byłoby zbadanie podobnych kooperacji na polu architektury czy projektowania urbanistycznego. Warto również wspomnieć o szczególnie ciekawych efektach kilku przypadków partnerstwa pisarsko- i poetycko-plastycznego tego czasu, które stanowią oddzielny, zresztą lepiej zbadany już problem (Rypson, 1992, 2017; Sobieraj, 2017). Współprace tego rodzaju, jako że nie należą wyłącznie do domeny projektowania graficznego, nie zostały ujęte $\mathrm{w}$ zestawieniu. Jednak granica ta niekiedy zaciera się — jak choćby w przypadku studia Reklama-Mechano, w którym obok grafika pracowali przecież zawodowi pisarze.

Jak już wspomniano, większość odnotowanych w wykazie firm i spółek ulokowana była w Warszawie, w tym czasie głównym ośrodku sztuki użytkowej w Polsce. Nie oznacza to jednak, że opisywany tutaj trend był nieobecny poza stolicą. Odnaleziono przykłady, choć mniej liczne, działalności spółek każdego z trzech typów, które zawiązywane były w innych miastach, przede wszystkim Lwowie, Poznaniu i Krakowie. Wskazuje nam to na fakt, że trend ten, choć w mniejszym stopniu, objął swoim zasięgiem nie tylko środowisko projektantów warszawskich.

W kolejnych częściach niniejszego artykułu scharakteryzowane zostały trzy wspomniane już wcześniej typy spółek. Każdemu z tych opisów towarzyszy wykaz odnalezionych i zidentyfikowanych podmiotów, przedstawiony w postaci uporządkowanej chronologicznie tabeli. Należy jeszcze raz podkreślić, że listy te, mimo starań autora, nie są zapewne kompletne. Ich celem jest zilustrowanie pewnego trendu i mają one stanowić przyczynek do bardziej szczegółowego zbadania fenomenu spółek artystycznych międzywojnia. 


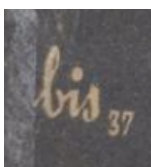

Wspólny monogram B. Bocianowskiego

i W. Szomańskiego

Znak Atelier Grafik

Wspólna sygnatura F. Weinles i S. Themersona
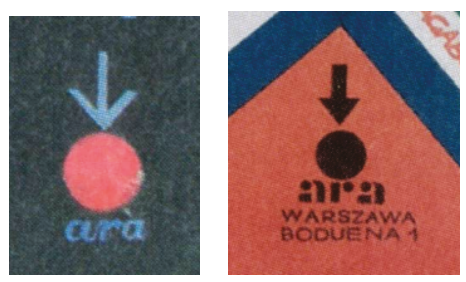

Znaki Atelier Ara w dwóch wariantach

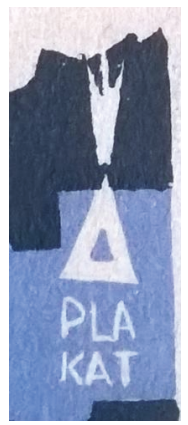

Znak Atelier Plakat

Znak wytwórni artystyczno-reklamowej Fama 


\section{KOOPERACJE ARTYSTYCZNE O CHARAKTERZE OKAZJONALNYM}

W pierwszym zestawieniu uwzględniono kooperacje dwóch lub trzech artystów, które zawiązywane były na krótki czas. Takie inicjatywy można nazwać partnerstwami okazjonalnymi czy też epizodycznymi. Były one tworzone w celu realizacji konkretnego projektu - najczęściej plakatu konkursowego. Niekiedy takie kooperacje obejmowały przygotowanie kilku wspólnych prac - na przykład seria ośmiu okładek autorstwa J. Levitta i J. Krajewskiego, które jednak nie zapoczątkowały stałej współpracy.

Zdarzało się, że poszczególne tandemy reaktywowały się kilkukrotnie przy okazji oddalonych niekiedy nawet o dekadę projektów. Najwięcej takich wspólnych twórczych „epizodów” mieli Andrzej Stypińśki i Jerzy Hryniewiecki (co najmniej pięć prac w latach 1929-1938) oraz Adam Bowbelski i Zygmunt Gorski (co najmniej osiem prac w latach 1929-1936). Takiego rodzaju partnerstwa również uznano za okazjonalne, gdyż w międzyczasie artyści pracowali przeważnie osobno (lub wchodzili w inne relacje), a same spółki raczej nie miały formy stałej, sformalizowanej współpracy. Sygnalizuje to nam jednak, że granica między współpracą podejmowaną okazjonalnie a pracą w ramach spółki jest niekiedy trudna do wyznaczenia.

W sumie udało się ustalić 71 okazjonalnych partnerstw dwóch lub trzech twórców. Dwa tandemy artystyczne pozostają jedynie domniemane, a ich skład osobowy nie jest pewny. W tabeli informacje takie zamieszczono w polu przeznaczonym na uwagi.

W odniesieniu do pierwszych dwóch dekad XX wieku udało się odnaleźć jedynie dwie prace plakatowe sygnowane przez dwóch współpracujących z sobą artystów — z 1913 i 1918 roku. Trend ten zyskał na popularności dopiero w kolejnym dziesięcioleciu, kiedy powstało już co najmniej dziesięć podobnych inicjatyw. Upowszechnienie się takiego modelu pracy przypada jednak przede wszystkim na lata trzydzieste. W tym czasie zawiązywało się nawet kilka takich krótkotrwałych partnerstw rocznie.

Przedstawiona chronologia w niektórych przypadkach może nie być dokładna. Wynika to przede wszystkim z trudności w datowaniu niektórych projektów (zwłaszcza plakatów i druków reklamowych) oraz nieuniknionej niekompletności zbioru prac i wzmianek źródłowych, do jakich udało się dotrzeć.

Wśród analizowanych partnerstw najczęściej spotykamy artystyczne tandemy, jednak odnotowano również osiem przypadków, gdy pracę nad jednym projektem podjęła trójka artystów. Większość z nich uczestniczyła także wcześniej lub później w innych kooperacjach, co można uznać za pewien wyraz satysfakcji z pracy zespołowej. 
Najwięcej spośród odnalezionych projektów, będących efektem okazjonalnej współpracy między artystami, powstało w Warszawie. Jest to oczywiste, biorąc pod uwagę, że stolica w tym czasie była centrum krajowego ruchu wydawniczego oraz siedzibą większości znaczących instytucji i przedsiębiorstw zainteresowanych działalnością reklamową. W związku z tym to właśnie tam skupiała się w okresie międzywojennym najliczniejsza grupa artystów związanych ze sztuką użytkową. Również w Warszawie najwcześniej rozwinął się i zyskał popularność trend kooperacyjnej pracy artystycznej.

Pojawiające się w poniższym zestawieniu inne ośrodki, jak Poznań, Kraków, Lwów, wskazują nam, że trend łączenia się w twórcze tandemy wykraczał poza środowisko artystów stołecznych. Skala tego zjawiska była mniejsza ze względu na odpowiednio mniejszy rynek sztuki użytkowej w tych miastach. Niewielka liczba odnotowanych przypadków kooperacji może też być spowodowana trudniejszym dostępem do zachowanych prac, zwłaszcza powstałych na terenach, które po II wojnie światowej znalazły się poza wschodnimi granicami Polski.

Zdarzały się przypadki współpracy na polu projektowania okładek, aranżacji wystaw czy stoisk sklepowych, jednak wśród artystów podejmujących krótkotrwałe partnerstwa dominują twórcy plakatów. Taki rodzaj współpracy zyskał popularność wśród plakacistów lat trzydziestych, a prace sygnowane przez tandemy artystyczne zajmowały czołowe miejsca w wielu konkursach na plakaty reklamowe i propagandowe. Świadczy to o wysokim poziomie wspólnych dzieł, które często musiały mierzyć się z konkurencją w postaci setek nadesłanych projektów konkursowych. Przytaczane w tabeli dane na temat nagród oparte są w dużej mierze na ustaleniach Sz. Bojki (1971).

Szczególnie wyraźna jest tendencja do konstytuowania się tego typu spółek w środowisku studentów i absolwentów Wydziału Architektury Politechniki Warszawskiej przy okazji konkursów plakatowych. Dość wcześnie zaczęli oni uczestniczyć w różnego rodzaju kooperacjach — początkowo przede wszystkim na polu architektury, jednak szybko docenili atuty tego modelu pracy także przy projektach graficznych. Wydaje się, że atmosfera i program nauczania na powstałym w 1915 roku Wydziale sprzyjały integracji studentów i absolwentów. Już w 1916 roku założony został prężnie działający Związek Słuchaczów Architektury, który wiele uwagi poświęcał zagadnieniom sztuki użytkowej.

Obok kilku dwu- i trzyosobowych zespołów, które przerodziły się w trwalsze spółki, obserwować można liczne, okazjonalnie zawiązywane współprace, których efektem było powstanie najczęściej jednego lub kilku wspólnie sygnowanych dzieł. W rozmaitych konfiguracjach, najczęściej przy okazji konkursów na plakaty, w podobnych kooperacjach brali udział między innymi: Maciej Nowicki, Stanisława Sandecka, Stefan Osiecki, Konstanty Sopoćko, Jerzy Skolimowski, J. Hryniewiecki, Andrzej Stypiński, A. Bowbelski, Stanisław Jankowski, Przemy- 
sław Siwik, Witold Janowski, Czesław Wielhorski, Władysław Radliński, Roman Wyłcan, Kazimierz Jodzewicz, Stefan Jelnicki, Wacław Hryniewicz, T. Gronowski, Bolesław Przyłuski, Edward Dodacki, Leszek Piątkowski, Jan Poliński, Jan Gotthelf Knothe, J.E. Mucharski, Marian Spychalski, Bruno Zborowski. Byli to twórcy zarówno starszego, jak i młodszego pokolenia projektantów, którzy kształcili się na Politechnice Warszawskiej (Parszewska, 2005). Jak wspomniano we wstępie, więcej uwagi zarówno krótkotrwale, jak i długo działającym spółkom zawieranym między nimi poświęciła w swym artykule M. Zdrenka (2013d).

Drugą uczelnią, która odgrywała ważną rolę w kształceniu na polu sztuk stosowanych, była warszawska Szkoła Sztuk Pięknych (dalej: SSP). Duże zasługi w edukacji młodych plastyków w zakresie sztuki użytkowej miały przede wszystkim pracownie profesorów Bartłomiejczyka, Skoczylasa, Jastrzębowskiego i Pruszkowskiego. Obok KAGR środowiska artystów związanych z SSP integrowały dodatkowo stowarzyszenia takie jak Blok Zawodowych Artystów Plastyków, Towarzystwo Szerzenia Sztuki Polskiej wśród Obcych czy Spółdzielnia Artystyczna Ład. Absolwenci uczelni często tworzyli wspólne grupy artystyczne, wśród których wymienić można między innymi Ryt, Czerń i Biel, Bractwo św. Łukasza, Szkołę wolnomalarską, Formę (Chmielewska, 1994). Istniały też mniej formalne społeczności skupiające sympatyków awangardowych czasopism, jak „Blok” czy „Zwrotnica”. Znajomości zawierane w czasie studiów lub w ramach zrzeszeń i formacji artystycznych przeradzały się niekiedy w różnego rodzaju wspólne twórcze inicjatywy.

Jak łatwo można zaobserwować w przedstawionej tabeli, często powtarzają się w różnych konfiguracjach nazwiska tych samych twórców. Można wręcz wskazać grupę artystów, którzy, jak można przypuszczać, bardzo chętnie brali udział w takich epizodycznych inicjatywach. Prym wiodą tutaj A. Stypiński (pięć partnerstw), J. Hryniewiecki (cztery partnerstwa oraz późniejsza spółka autorska z S. Osieckim) i Henryk Jaworski (cztery współprace). Wysoko oceniane efekty wspólnej pracy skłaniały niekiedy artystów do kolejnych wspólnych przedsięwzięć. Na przestrzeni lat wielokrotnie podejmowali współpracę między innymi Stypiński i Hryniewiecki oraz Bowbelski i Z. Gorski. Nie jest pewne, czy tych kooperacji nie należałoby traktować jako spółek autorskich, jednak z braku wystarczających źródeł potraktowano je jako powtarzalne partnerstwa okazjonalne.

Wielu spośród artystów biorących udział w podobnych inicjatywach wcześniej lub później zawiązywało także poważniejsze, bardziej formalne spółki autorskie. Świadczyć to może o zaakceptowaniu przez nich kooperacyjnego modelu pracy artystycznej, w której dobrze się odnajdywali. Niektórzy twórcy podejmujący tego typu współpracę mieli wcześniej doświadczenia w pracy w zorganizowanych studiach graficznych. Inni z kolei, zachęceni efektywnością wspólnego działania, sami zakładali niekiedy spółki autorskie. Przykładem może być tutaj między innymi Jan Levitt, stawiający pierwsze kroki w Atelier Grafik Emila 
Lindemanna. W kolejnych latach, już jako niezależny artysta, podejmował epizodyczne współprace z Leonem Chejfecem i Juliuszem Krajewskim, by w końcu stworzyć wspólnie z Jerzym Himem działającą ponad dwadzieścia lat spółkę autorską. Za kolejne przykłady posłużyć mogliby również z pewnością Tadeusz Gronowski czy Jan Emil Mucharski, których liczne spółki i angaże w studiach graficznych, tworzą długą listę. Działające przez długi czas spółki, a nawet artystyczne małżeństwa, narodziły się również w kręgu absolwentów Wydziały Architektury. Spośród licznych wymienionych konfiguracji trwałe okazały się tandemy Osiecki-Skolimowski, Nowicki-Sandecka, Hryniewiecki-Osiecki, które ujęto w kolejnym zestawieniu.

Dane przedstawione w poniższej tabeli ustalono przede wszystkim na podstawie odnalezionych wspólnie sygnowanych prac oraz opublikowanych opracowań dotyczących polskiego plakatu i sztuki użytkowej międzywojnia, w których odnotowano duety i tria działające na tym polu lub ich dzieła. Niektóre z wymienionych tu partnerstw mogły mieć w rzeczywistości większy dorobek niż zostało to wykazane. Inne, z uwagi na brak źródeł lub ograniczoną ich dostępność, mogły nie zostać uwzględnione.

Tab. 1. Przedwojenne kooperacje artystyczne o charakterze okazjonalnym

\begin{tabular}{|l|l|l|}
\hline Chronologia & \multicolumn{1}{|c|}{ Partnerzy } & \multicolumn{1}{c|}{ Dodatkowe informacje } \\
\hline 1913 & $\begin{array}{l}\text { Czesław Młodzianowski, } \\
\text { Wacław Zbigniew Czerny }\end{array}$ & Znany jeden plakat. \\
\hline 1918 & $\begin{array}{l}\text { Tadeusz Gronowski, } \\
\text { Wojciech Główczewski }\end{array}$ & $\begin{array}{l}\text { Znany jeden plakat. Być może praca powstała } \\
\text { w ramach działalności Gronowskiego w Studiu } \\
\text { Litografii W. Główczewskiego. }\end{array}$ \\
\hline 1926 & $\begin{array}{l}\text { Henryk Berlewi, } \\
\text { Szymon Syrkus }\end{array}$ & $\begin{array}{l}\text { Projekty stoisk reklamowych. Nie zachowała się } \\
\text { prawdopodobnie żadna dokumentacja tych pro- } \\
\text { jektów (Frankowski, Frankowska, 2009). }\end{array}$ \\
\hline 1927 & $\begin{array}{l}\text { Andrzej Stypiński, } \\
\text { Stefan Bąk, } \\
\text { Władysław Radliński }\end{array}$ & $\begin{array}{l}\text { Znany jeden plakat: I miejsce w konkursie na } \\
\text { plakat dla PLL Aerolot. }\end{array}$ \\
\hline około 1927 & $\begin{array}{l}\text { Kazimierz Jodzewicz, } \\
\text { Czesław Knothe }\end{array}$ & \begin{tabular}{l} 
Znany jeden plakat. \\
\hline 1927 i 1933
\end{tabular} \\
$\begin{array}{l}\text { Jan Emil Mucharski, } \\
\text { Tadeusz Kubalski }\end{array}$ & $\begin{array}{l}\text { Znane dwie prace plakatowe. W 1933 roku } \\
\text { IV nagroda w konkursie na plakat Państwowej } \\
\text { Loterii Klasowej. }\end{array}$ \\
\hline 1927 & $\begin{array}{l}\text { Wilkoński, Tuszowski, } \\
\text { Kinkin }\end{array}$ & $\begin{array}{l}\text { Znana jedna praca: III miejsce w konkursie na } \\
\text { plakat VIII Międzynarodowego Targu Poznań- } \\
\text { skiego. }\end{array}$ \\
\hline
\end{tabular}




\begin{tabular}{|c|c|c|}
\hline 1928 & $\begin{array}{l}\text { Zygmunt Lorec, } \\
\text { Mieczysław Jurgielewicz, } \\
\text { Kazimierz Jodzewicz }\end{array}$ & $\begin{array}{l}\text { Znana jedna praca: III miejsce w konkursie na } \\
\text { plakat Powszechnej Wystawy Krajowej w Pozna- } \\
\text { niu w } 1929 \text { roku. }\end{array}$ \\
\hline 1928 & C. i G. Nagabczyńscy & $\begin{array}{l}\text { Znany jeden plakat dla producenta wełny Trójkąt } \\
\text { w Kole, wykony w ramach pracy dla Atelier Ara. } \\
\text { Prawdopodobnie małżeństwo (lub rodzeństwo). }\end{array}$ \\
\hline $\begin{array}{l}1929,1930 \\
1931 \text { i } 1938\end{array}$ & $\begin{array}{l}\text { Andrzej Stypińśki, } \\
\text { Jerzy Hryniewiecki }\end{array}$ & $\begin{array}{l}\text { Znane pięć projektów: w } 1929 \text { roku wspólne } \\
\text { prace tandemu zdobyły I i II nagrodę w konkur- } \\
\text { sie na plakat dla Fabryki olejów Polmin; w tym } \\
\text { samym roku artyści zdobyli również I nagrodę } \\
\text { w konkursie na plakat Państwowej Wytwórni } \\
\text { Prochu i Materiałów Kruszących Zagożdżon; } \\
1930 \text { rok - I nagroda w konkursie na plakat } \\
\text { X Jubileuszowych Targów Wschodnich; } 1931 \text { rok } \\
\text { - II nagroda w konkursie na plakat Balu Młodej } \\
\text { Architektury; } 1938 \text { rok - II nagroda w konkursie } \\
\text { na plakat Narciarskich Mistrzostw Świata organi- } \\
\text { zowanych przez FIS w Zakopanem w } 1939 \text { roku. }\end{array}$ \\
\hline 1929 & $\begin{array}{l}\text { Irena Kuczborska, } \\
\text { Stefan Gałkowski }\end{array}$ & $\begin{array}{l}\text { Znana jedna praca: I miejsce w konkursie na trzy } \\
\text { plakaty dla Arcyksiążęcego Browaru w Żywcu. }\end{array}$ \\
\hline $\begin{array}{l}1929,1930 \\
1931,1932 \\
1933,1934, \\
1935 \text { i } 1936\end{array}$ & $\begin{array}{l}\text { Adam Bowbelski, } \\
\text { Zygmunt Gorski }\end{array}$ & $\begin{array}{l}\text { Artyści na przestrzeni lat wielokrotnie podej- } \\
\text { mowali współpracę, odnosząc liczne sukcesy } \\
\text { na polu plakatu. W } 1929 \text { roku I miejsce w kon- } \\
\text { kursie na afisz Dnia Spółdzielczości; } 1930 \text { rok } \\
\text { — II nagroda w konkursie na plakat Balu Młodej } \\
\text { Architektury; } 1931 \text { rok - I nagroda w konkursie } \\
\text { na plakat Balu Młodej Architektury; } 1932 \text { rok - } \\
\text { III miejsce w konkursie na plakat Państwowej } \\
\text { Loterii Klasowej; } 1933 \text { rok - III nagroda w kon- } \\
\text { kursie na plakat Państwowej Loterii Klasowej; } \\
\text { 1934 rok — I nagroda w konkursie na plakat dla } \\
\text { Państwowego Monopolu Spirytusowego; 1935 } \\
\text { rok - II nagroda w konkursie na plakat Balu } \\
\text { Młodej Architektury; 1936 rok - I nagroda } \\
\text { w konkursie na plakat, „Jedz ryby”. }\end{array}$ \\
\hline 1929 & $\begin{array}{l}\text { Władysław Lewandowski, } \\
\text { Bolesław Przyłuski }\end{array}$ & $\begin{array}{l}\text { Znana jedna praca: III nagroda w konkursie na } \\
\text { plakat dla Fabryki olejów Polmin. }\end{array}$ \\
\hline 1930 i 1938 & $\begin{array}{l}\text { Janusz Alchimowicz, } \\
\text { Stanisław Albrecht }\end{array}$ & $\begin{array}{l}\text { Znany jeden plakat z } 1930 \text { roku oraz dwa wspól- } \\
\text { ne projekty architektoniczne z } 1938 \text { roku. }\end{array}$ \\
\hline 1930 i 1933 & $\begin{array}{l}\text { Tadeusz Gronowski, } \\
\text { Felicjan Kowarski }\end{array}$ & $\begin{array}{l}\text { Znane dwie prace: w } 1930 \text { roku II nagroda } \\
\text { w konkursie na plakat z okazji obchodów stulecia } \\
\text { powstania listopadowego; } 1933 \text { rok - I nagroda } \\
\text { w konkursie na plakat promujący Państwową } \\
\text { Odznakę Sportową. }\end{array}$ \\
\hline
\end{tabular}




\begin{tabular}{|c|c|c|}
\hline 1930 & $\begin{array}{l}\text { Bolesław Surałło, } \\
\text { Tadeusz Kryszak }\end{array}$ & $\begin{array}{l}\text { Znana jedna praca: I nagroda w konkursie na } \\
\text { plakat } \mathrm{z} \text { okazji obchodów stulecia powstania } \\
\text { listopadowego. }\end{array}$ \\
\hline 1930 & $\begin{array}{l}\text { Henryk Czaman, } \\
\text { Kazimierz Idczak }\end{array}$ & $\begin{array}{l}\text { Znana jedna praca: I nagroda w konkursie na } \\
\text { plakat Międzynarodowych Targów w Poznaniu. }\end{array}$ \\
\hline 1930 & $\begin{array}{l}\text { Zbigniew Czech, } \\
\text { Eugeniusz Wierzbicki }\end{array}$ & $\begin{array}{l}\text { Znana jedna praca: II nagroda w konkursie na } \\
\text { plakat Międzynarodowych Targów w Poznaniu. }\end{array}$ \\
\hline 1930 & $\begin{array}{l}\text { Jerzy Kierzkowski, } \\
\text { Eugeniusz Wierzbicki }\end{array}$ & $\begin{array}{l}\text { Znana jedna praca: III nagroda w konkursie na } \\
\text { plakat X Jubileuszowych Targów Wschodnich. }\end{array}$ \\
\hline 1930 & $\begin{array}{l}\text { Franciszka Weinless- } \\
\text {-Themerson, } \\
\text { Stefan Themerson }\end{array}$ & $\begin{array}{l}\text { Jedna wspólnie sygnowana graficzna aranżacja } \\
\text { wiersza } W \text { kinie; poza tym współpraca literacko- } \\
\text {-ilustratorska. } \\
\text { Stefan i Franciszka Themersonowie tworzyli } \\
\text { zgrany duet pisarsko-ilustratorski. Choć Stefan } \\
\text { realizował się przede wszystkim na polu litera- } \\
\text { ckim, znana jest jedna sygnowana jego inicjałami } \\
\text { praca plastyczna, która zapewne powstała przed } \\
\text { ślubem z Franciszką (inicjały „FW”, nie „FT”). }\end{array}$ \\
\hline 1931 i 1934 & $\begin{array}{l}\text { Maciej Nowicki, } \\
\text { Stanisława Sandecka, } \\
\text { Adam Bowbelski }\end{array}$ & Znane dwa plakaty. \\
\hline 1931 i 1935 & $\begin{array}{l}\text { Jan Poliński, } \\
\text { Bolesław Przyłuski }\end{array}$ & Znane dwa plakaty. \\
\hline 1932 & $\begin{array}{l}\text { Juliusz Kieszkowski, } \\
\text { Eugeniusz Wierzbicki }\end{array}$ & Lwów. Jeden znany plakat. \\
\hline 1932 i 1934 & $\begin{array}{l}\text { Henryk Jaworski, } \\
\text { Tadeusz Kryszak }\end{array}$ & $\begin{array}{l}\text { Znane dwie prace: w } 1932 \text { roku II miejsce w kon- } \\
\text { kursie na plakat Państwowej Loterii Klasowej; } \\
1934 \text { rok - III miejsce w konkursie na plakat dla } \\
\text { Państwowego Monopolu Spirytusowego. }\end{array}$ \\
\hline około 1933 & $\begin{array}{l}\text { Jan Levitt, } \\
\text { Juliusz Krajewski }\end{array}$ & $\begin{array}{l}\text { Znana jest seria ośmiu okładek książkowych dla } \\
\text { Nowego Wydawnictwa w Warszawie. }\end{array}$ \\
\hline $\begin{array}{l}1933,1934 \\
\text { i } 1937\end{array}$ & $\begin{array}{l}\text { Andrzej Stypiński, } \\
\text { Jerzy Skolimowski }\end{array}$ & $\begin{array}{l}\text { Znane trzy plakaty; w } 1933 \text { roku II nagroda } \\
\text { w konkursie na plakat reklamowy „Włóczki, } \\
\text { wełny — Trójkąt w Kole”. }\end{array}$ \\
\hline 1933 i 1935 & $\begin{array}{l}\text { Jan Gotthelf Knothe, } \\
\text { Tadeusz Niedbalski }\end{array}$ & $\begin{array}{l}\text { Znane dwa plakaty przygotowane na warszawski } \\
\text { Bal Architekta. }\end{array}$ \\
\hline 1933 & $\begin{array}{l}\text { Zygmunt Glinicki, } \\
\text { Felicjan Kowarski }\end{array}$ & $\begin{array}{l}\text { Znana jedna praca; IV nagroda w konkursie na } \\
\text { plakat reklamowy „Włóczki, wełny — Trójkąt } \\
\text { w Kole”. }\end{array}$ \\
\hline
\end{tabular}




\begin{tabular}{|c|c|c|}
\hline 1933 & $\begin{array}{l}\text { Leon Chejfec, } \\
\text { Jan Levitt }\end{array}$ & $\begin{array}{l}\text { Znana jedna okładka książkowa. Artyści współ- } \\
\text { pracowali wcześniej w Agencji Grafik, między } \\
\text { innymi przy reklamach dla przemysłu cukrowni- } \\
\text { czego. }\end{array}$ \\
\hline 1933 & $\begin{array}{l}\text { Zygmunt Strychulski, } \\
\text { Jan Marcin Szancer }\end{array}$ & $\begin{array}{l}\text { Jedna znana praca: III nagroda w konkursie na } \\
\text { plakat reklamowy „Fosfatyna Faliera” dla formy } \\
\text { Asmidar. }\end{array}$ \\
\hline około 1933 & $\begin{array}{l}\text { Tadeusz Lipski, } \\
\text { Adam Krzeptowski } \\
\text { (fotograf i filmowiec) }\end{array}$ & Kraków. \\
\hline 1933 i 1934 & $\begin{array}{l}\text { Wanda Wernerowa, } \\
\text { Wanda Borowska }\end{array}$ & $\begin{array}{l}\text { Dwie znane prace; w } 1933 \text { roku I nagroda za pla- } \\
\text { kat dla Państwowego Monopolu Spirytusowego; } \\
1934 \text { rok — plakat dla PLL LOT. }\end{array}$ \\
\hline 1933 & $\begin{array}{l}\text { Jan Knothe, } \\
\text { Tadeusz Niedbalski }\end{array}$ & Znany jeden plakat. \\
\hline 1933 & $\begin{array}{l}\text { Jan Poliński, } \\
\text { Dziaba Wróblewska, } \\
\text { Tadeusz Dzięgielewski }\end{array}$ & $\begin{array}{l}\text { Znana jedna praca: I nagroda w konkursie na } \\
\text { plakat reklamowy „Włóczki, wełny — Trójkąt } \\
\text { w Kole”. }\end{array}$ \\
\hline 1934 & $\begin{array}{l}\text { Stefan Plater-Zyberk, } \\
\text { M. Obrębska }\end{array}$ & Znany jeden plakat. \\
\hline 1934 & $\begin{array}{l}\text { Henryk Jaworski, } \\
\text { Antoni Łyżwański }\end{array}$ & $\begin{array}{l}\text { Znana jedna praca: I nagroda w konkursie na } \\
\text { plakat „Propagujcie poradnictwo przedślubne”. }\end{array}$ \\
\hline 1934 & $\begin{array}{l}\text { Aleksander Rak, } \\
\text { Henryk Jaworski, } \\
\text { Tadeusz Kryszak }\end{array}$ & $\begin{array}{l}\text { Znana jedna praca: II nagroda w konkursie na } \\
\text { plakat dla Państwowego Monopolu Spirytuso- } \\
\text { wego. }\end{array}$ \\
\hline 1934 & $\begin{array}{l}\text { Jerzy Hryniewiecki, } \\
\text { Maciej Nowicki, } \\
\text { Stanisława Sandecka, }\end{array}$ & $\begin{array}{l}\text { Znane dwie prace: I i IV nagroda w konkursie na } \\
\text { plakat dla Ligi Morskiej i Kolonialnej. }\end{array}$ \\
\hline 1934 & $\begin{array}{l}\text { Olgierd Tarnowski, } \\
\text { M. Pawluć }\end{array}$ & $\begin{array}{l}\text { Znana jedna praca: II nagroda w konkursie na } \\
\text { plakat dla Ligi Morskiej i Kolonialnej. }\end{array}$ \\
\hline 1934 & $\begin{array}{l}\text { Janusz Alchimowicz, } \\
\text { Stanisław Kostecki }\end{array}$ & $\begin{array}{l}\text { Znane dwie prace: II nagroda w konkursie na } \\
\text { plakat „Potas obdarzy Was urodzajem”; I nagroda } \\
\text { w konkursie na plakat „Gdynia”. }\end{array}$ \\
\hline $\begin{array}{l}\text { około 1934- } \\
1935\end{array}$ & $\begin{array}{l}\text { Bolesław Przyłuski, } \\
\text { Stefan Jelnicki }\end{array}$ & Znany jeden plakat. \\
\hline $\begin{array}{l}\text { około } 1934- \\
1935\end{array}$ & $\begin{array}{l}\text { Juliusz Krajewski, } \\
\text { Bolesław Przyłuski }\end{array}$ & Znany jeden plakat dla Monopolu Spirytusowego. \\
\hline
\end{tabular}




\begin{tabular}{|c|c|c|}
\hline 1934 & $\begin{array}{l}\text { Stanisław Jankowski, } \\
\text { Przemysław Siwik }\end{array}$ & Znany jeden projekt zaproszenia. \\
\hline 1934 & $\begin{array}{l}\text { Ludwik Gardowski, } \\
\text { Mieczysław Jurgielewicz }\end{array}$ & $\begin{array}{l}\text { Znana jedna okładka przygotowana do katalogu } \\
\text { wystawy sztuki polskiej w Rydze. }\end{array}$ \\
\hline około 1934 & $\begin{array}{l}\text { Witold Janowski, } \\
\text { Przemysław Siwik }\end{array}$ & $\begin{array}{l}\text { M. Łącka wspomina o jednej pracy plakatowej } \\
\text { autorstwa tej dwójki, prezentowanej na wystawie } \\
\text { Związku Słuchaczów Architektury Politechniki } \\
\text { Warszawskiej w Zachęcie w } 1934 \text { roku. }\end{array}$ \\
\hline 1934 & $\begin{array}{l}\text { Tadeusz Trepkowski, } \\
\text { Mieczysław Przybylski }\end{array}$ & $\begin{array}{l}\text { Znana jedna praca: III nagroda w konkursie na } \\
\text { plakat dla Pocztowej Kasy Oszczędnościowej. }\end{array}$ \\
\hline 1934 & $\begin{array}{l}\text { Maria Rogowska, } \\
\text { Bolesław Surałło }\end{array}$ & $\begin{array}{l}\text { Znana jedna praca: III nagroda w konkursie na } \\
\text { plakat Państwowej Loterii Klasowej. }\end{array}$ \\
\hline 1935 & $\begin{array}{l}\text { Mieczysław Różański, } \\
\text { Roman Wyłcan }\end{array}$ & Znany jeden plakat. \\
\hline 1935 & $\begin{array}{l}\text { Jan Poliński, } \\
\text { Jerzy Alchimowicz }\end{array}$ & $\begin{array}{l}\text { Znana jedna praca: II nagroda w konkursie na } \\
\text { plakat „Bratnia pomoc”. }\end{array}$ \\
\hline 1935 & $\begin{array}{l}\text { Hanna Dąbrowska, } \\
\text { Jan Słomczyński }\end{array}$ & $\begin{array}{l}\text { Znany jeden projekt: II nagroda w konkursie } \\
\text { na tablice reklamowe dla Browaru Książęcego } \\
\text { w Tychach. }\end{array}$ \\
\hline 1935 & $\begin{array}{l}\text { Henryk Jaworski, } \\
\text { Władysław Koch }\end{array}$ & $\begin{array}{l}\text { Znany jeden projekt: II nagroda w konkursie na } \\
\text { wywieszki wagonowe dla Browaru Książęcego } \\
\text { w Tychach. }\end{array}$ \\
\hline 1935 & $\begin{array}{l}\text { Stefan Osiecki, } \\
\text { Andrzej Stypiński }\end{array}$ & $\begin{array}{l}\text { Seria prac reklamowych i opakowań dla firmy } \\
\text { Wedel. }\end{array}$ \\
\hline 1935 & $\begin{array}{l}\text { Lonah Kruszewska, } \\
\text { Wojciech Meyer }\end{array}$ & Znany jeden plakat. \\
\hline 1935 & $\begin{array}{l}\text { Tadeusz Trepkowski, } \\
\text { Tadeusz Piotrowski }\end{array}$ & $\begin{array}{l}\text { Partnerstwo nieudokumentowane pracami. In- } \\
\text { formacja o tej współpracy pochodzi z biogramu } \\
\text { Trepkowskiego w „Przeglądzie Artystycznym” } \\
\text { z } 1955 \text { roku. }\end{array}$ \\
\hline 1936 & $\begin{array}{l}\text { Jerzy Karolak, } \\
\text { Konstanty Sopoćko }\end{array}$ & Znany jeden plakat dla Polskiej Ligi Kolonialnej. \\
\hline $1936-1939$ & $\begin{array}{l}\text { Czesław Wielhorski, } \\
\text { Leszek Piątkowski }\end{array}$ & $\begin{array}{l}\text { Wykonali wspólnie kilka plakatów konkurso- } \\
\text { wych, między innymi: } \\
\text { w } 1936 \text { roku dwa projekty plakatów ostrzegaw- } \\
\text { czych dla Instytutu Spraw Społecznych; } 1938 \\
\text { rok - co najmniej dwa plakaty, w tym I nagroda } \\
\text { w konkursie na plakat Narciarskich Mistrzostw } \\
\text { Świata w Zakopanem w } 1939 \text { roku. }\end{array}$ \\
\hline
\end{tabular}




\begin{tabular}{|c|c|c|}
\hline 1937 & $\begin{array}{l}\text { Wacław Machan, } \\
\text { Czesław Wielhorski }\end{array}$ & Znany jeden plakat. \\
\hline 1937 & $\begin{array}{l}\text { Marian Spychalski, } \\
\text { Bruno Zborowski }\end{array}$ & Znany jeden plakat. \\
\hline 1936 i 1937 & $\begin{array}{l}\text { Edward Dodacki, } \\
\text { Wacław Hryniewicz }\end{array}$ & $\begin{array}{l}\text { Znane pięć prac; w } 1936 \text { r. cztery projekty pla- } \\
\text { katów ostrzegawczych dla Instytutu Spraw Spo- } \\
\text { łecznych. }\end{array}$ \\
\hline $1937-1939$ & $\begin{array}{l}\text { Bohdan Bocianowski, } \\
\text { Władysław Szomański }\end{array}$ & $\begin{array}{l}\text { Znane kilka prac plakatowych i jedna okładka dla } \\
\text { Reklamy Pocztowej. }\end{array}$ \\
\hline 1937 & $\begin{array}{l}\text { Gwidon Budecki, } \\
\text { Władysław Sowicki }\end{array}$ & $\begin{array}{l}\text { Znana jedna praca: II nagroda w konkursie na } \\
\text { plakat reklamowy dla Polskiego Przemysłu Wód- } \\
\text { czanego. }\end{array}$ \\
\hline 1937,1938 & $\begin{array}{l}\text { Władysław Wasilewski, } \\
\text { Zygmunt Strychalski }\end{array}$ & $\begin{array}{l}\text { Znane dwie prace: w } 1937 \text { roku II miejsce w kon- } \\
\text { kursie na plakat turystyczny dla miasta Krakowa; } \\
\text { w } 1938 \text { roku IV miejsce w konkursie na plakat } \\
\text { Narciarskich Mistrzostw Świata w Zakopanem } \\
\text { w } 1939 \text { roku. }\end{array}$ \\
\hline 1938 & $\begin{array}{l}\text { Andrzej Stypińśki, } \\
\text { Alina Hryniewiecka, } \\
\text { Jerzy Hryniewiecki }\end{array}$ & $\begin{array}{l}\text { Projekt Sali Przemysłu Artystycznego dla Pawi- } \\
\text { lonu Polskiego na Wystawę Światową w Nowym } \\
\text { Jorku. }\end{array}$ \\
\hline 1938 & $\begin{array}{l}\text { Kazimierz Mann, } \\
\text { FRIED? }\end{array}$ & $\begin{array}{l}\text { Niepotwierdzone w źródłach, stwierdzono na } \\
\text { postawie nierozszyfrowanej sygnatury „FRIED”. } \\
\text { Znana jedna okładka dla Udziałowej Spółki Wy- } \\
\text { dawniczej w Krakowie. }\end{array}$ \\
\hline 1938 & $\begin{array}{l}\text { Henryk Smółko, } \\
\text { A. Niemczewska }\end{array}$ & Poznań. Znana jedna okładka. \\
\hline 1938 & $\begin{array}{l}\text { Franciszek Parecki, } \\
\text { igr? }\end{array}$ & $\begin{array}{l}\text { Parecki we współpracy z niezidentyfikowanym } \\
\text { artysta podpisanym ,igr”. Niepotwierdzone } \\
\text { w źródłach, stwierdzone na podstawie sygnatur. } \\
\text { Znane dwie okładki dla Towarzystwa Wydawni- } \\
\text { czego „Rój” oraz jedna dla Księgarni Popularnej. }\end{array}$ \\
\hline 1938 & $\begin{array}{l}\text { Stanisław Kaller, } \\
\text { Witold Janowski }\end{array}$ & Lwów? Znany jeden plakat. \\
\hline 1938 i 1939 & $\begin{array}{l}\text { Gwidon Budecki, } \\
\text { Zygmunt Kowalewski }\end{array}$ & $\begin{array}{l}\text { Znane dwie prace: w } 1938 \text { roku I nagroda w kon- } \\
\text { kursie na plakat dla Powszechnych Zakładów } \\
\text { Ubezpieczeń Wzajemnych; } 1939 \text { rok - I nagro- } \\
\text { da w konkursie na plakat reklamowy dla firmy } \\
\text { Leszczków. }\end{array}$ \\
\hline
\end{tabular}




\begin{tabular}{|l|l|l|}
\hline 1938 & $\begin{array}{l}\text { Stefan Osiecki, } \\
\text { Roman Serafin (foto- } \\
\text { grafik) }\end{array}$ & Znany jeden plakat. \\
\hline 1939 & $\begin{array}{l}\text { J. Niezabitowska, } \\
\text { L. Biernacka }\end{array}$ & Znana jedna okładka czasopisma „Wiarus”. \\
\hline 1939 & $\begin{array}{l}\text { Bohdan Bocianowski, } \\
\text { Władysław Szomański, } \\
\text { Henryk Tomaszewski }\end{array}$ & Znany jeden plakat. \\
\hline
\end{tabular}

\section{SPÓŁKI AUTORSKIE}

Obok krótkotrwałych artystycznych partnerstw w przedwojennej Polsce zaobserwować można również trwalsze formy wspólnego działania, znane najczęściej jako spółki autorskie, występujące pod różnymi nazwami — studio, atelier czy pracownia graficzna. Choć ilościowo stanowią one najmniej liczną grupę, w aspekcie jakościowym są z pewnością ważną częścią historii polskiego projektowania graficznego omawianego okresu. Tandemy takie jak Girs-Barcz, Levitt-Him, Osiecki-Skolimowski czy Nowicki-Sandecka to czołówka ówczesnych projektantów graficznych.

Spółki te działały znacznie dłużej niż opisane wcześniej partnerstwa okazjonalne. Najtrwalsza, bo przeszło dwudziestoletnia, okazała się współpraca Levitta i Hima, jednak ten przypadek jest dość szczególny, gdyż z racji wyjazdu obu artystów do Wielkiej Brytanii w 1937 roku ich działalności nie zakłóciła II wojna światowa. Podobne firmy funkcjonowały z reguły kilka lat, niekiedy nawet dekadę.

Za ich najwcześniejszy przykład można uznać tandem świetnych plakacistów Osiecki-Skolimowski, którzy działali od 1928 roku pod szyldem Spółki graficznej Decor. Najwięcej tego typu podmiotów powstało jednak w pierwszej połowie lat trzydziestych. Działalność większości z nich gwałtownie zakończył wybuch wojny. W sumie na przestrzeni nieco ponad dekady odnotować można dziesięć aktywnych spółek autorskich. Większość z nich funkcjonowała w Warszawie, jedna $\mathrm{w}$ Krakowie i jedna z pewnym prawdopodobieństwem we Lwowie. Niektóre z nich po wojnie kontynuowały działalność poza granicami kraju.

Przyczyny zawiązywania tego rodzaju spółek były rozmaite i częściowo przedstawiono je w części wstępnej. Najczęściej w skład takich partnerstw wchodzili młodzi artyści, dopiero zdobywający renomę w środowisku stołecznych projektantów. Angażując się w tego rodzaju spółki, oczekiwali oni zapewne stabilizacji oraz korzyści płynących z połączenia talentów i umiejętności. W ten sposób wzmacniał się potencjał intelektualny, przydatny przy pracy koncepcyjnej czy krytycznej ocenie efektów. Dywersyfikował się także wachlarz technik i umie- 
jętności, co otwierało nowe możliwości twórcze. Artyści łączyli również swe doświadczenie, wiedzę oraz kontakty rynkowe, które zdobywali wcześniej na własną rękę. Duch współpracy działał ponadto mobilizująco i pozwalał zwiększyć efektywność oraz motywację do osiągania jak najlepszych wyników.

Trwałość tych spółek wskazuje, że artyści wchodzący w ich skład musieli być zadowoleni z efektów wspólnej pracy. Częstokroć rezygnowali oni z działalności pod własnym nazwiskiem, wszystkie prace sygnując nazwą spółki. Z zachowanej umowy między Levittem i Himem wynika, że wszystkie dzieła, nawet te wykonane samodzielnie przez jednego z partnerów, wchodzą w dorobek spółki. Podobne praktyki można zauważyć w działalności tandemu Girs-Barcz. Inaczej wyglądały ustalenia członków Atelier Mewa, którzy obok prac opatrywanych nazwą firmy tworzyli też pod własnym nazwiskiem. Najczęściej działający razem artyści wspólnie sygnowali dzieła, a niekiedy używali również firmowego znaku — charakterystyczną mewę można znaleźć przy sygnaturach wiadomej spółki. Również Girs i Barcz obok swych nazwisk umieszczali zazwyczaj rzucający się w oczy monogram złożony z pierwszych liter ich nazwisk.

Niestety źródła na temat wewnętrznej organizacji oraz warsztatu większości z tych spółek są nad wyraz skąpe. Nieco światła na sposób ich funkcjonowania rzuca między innymi biografia Girsa, w której sporo miejsca poświęcono jego współpracy z Barczem. Dzięki bogatemu londyńskiemu archiwum George’a (Jerzego) Hima, obejmującemu po części także polski okres jego działalności, udało się odnaleźć również sporo ciekawych materiałów na temat Studia Levitt-Him² ${ }^{2}$. Działalność większości z wymienionych inicjatyw wciąż jednak pozostaje słabo opracowana, a jest to niewątpliwie temat wart większej uwagi badaczy, zważywszy na wysoki poziom artystyczny oraz liczebność prac będących efektem ich działalności.

Funkcjonowanie spółek autorskich jest tym bardziej ciekawą kwestią, że często nie ograniczało się wyłącznie do współpracy artystycznej. Związki między artystami opierały się również na przyjaźni, a niekiedy nawet miłości. Wśród odnotowanych spółek znalazły się trzy artystyczne małżeństwa: S. Sandeckiej i M. Nowickiego, A. Birtus i F. Seiferta oraz J. Hładki i A. Wajwóda, którzy wchodzili w skład Atelier Mewa. Zapewne J. i M. Leopoldstadtowie również byli małżeństwem lub rodzeństwem. Niestety nie udało się ustalić ich szczegółowych personaliów.

W innych spółkach również można zauważyć silne więzi między partnerami. B. Barcz na początku lat trzydziestych znajdował się w bardzo trudnej sytuacji — władze warszawskiej SSP skutecznie utrudniały mu znalezienie zatrudnienia,

${ }^{2}$ George Him's Archive - przechowywane w Archive of Art and Design, Victoria and Albert Museum w Londynie. 
mając mu za złe proces, jaki artysta wytoczył uczelni za zniszczenie jego rzeźby. Cierpiący na gruźlicę Barcz podupadł na zdrowiu i znalazł się na skraju nędzy. Usłyszawszy o jego niewesołym położeniu, z pomocą przyszedł A. Girs, proponując koledze spółkę artystyczną. Cieszył się on już w tym czasie sympatią oficerów kierujących Główną Księgarnia Wojskową, a tam naciski wywierane przez SSP nie miały już większego wpływu. Dużą odpowiedzialność i solidarność partnerską widać także na przykładzie Levitta i Hima. Artyści ci współpracowali z sobą tak blisko, że zdecydowali się wspólnie wyemigrować na stałe do Wielkiej Brytanii, gdzie planowali kontynuować swoją działalność graficzną. Ponadto, choć ich relacja była burzliwa i trudna, wspierali się w trudnych chwilach, jak podczas ciężkiej choroby Levitta w 1937 roku czy w 1947 roku, gdy Him przechodził poważną operację płuc. Jego partner zabrał go wówczas na rekonwalescencję do Irlandii, gdzie w tym czasie nie obowiązywały kartki żywnościowe. Podobnie silne więzi spajały członków Atelier Mewa - wszyscy troje studiowali razem w warszawskiej SSP w pracowni prof. Karola Tichego. Ich współpraca w ramach spółki była bardzo ścisła, a zdarzało się, że artyści ci podejmowali wspólne projekty nawet po jej rozpadzie (Chmielewska, 1994).

Twórcy współpracujący z sobą korzystali najczęściej ze wspólnej pracowni. Levitt i Him pierwszą siedzibę swojej debiutującej firmy ulokowali w rodzinnym mieszkaniu Himmelfarbów w centrum Warszawy. Z kolei rozwijana sukcesywnie i uzupełniana o nowe sprzęty pracownia Girsa i Barcza z czasem zaczęła przypominać pełnoprawną oficynę drukarską, będącą miejscem wspólnych eksperymentów i zapleczem do wydawania ekskluzywnych niskonakładowych druków.

W przypadku Levitta i Hima wspólne spędzanie czasu nie ograniczało się jedynie do godzin pracy. Artyści mieszkali bowiem razem (później także z żoną Levitta - Aliną) przez niemal cały londyński okres działalności Studia. Tak bliska relacja niosła z sobą ryzyko pewnych tarć, zwłaszcza między twórcami o różnych temperamentach $i$ charakterach. Niestety niewiele wiadomo na temat tego typu relacji między partnerami, jednak ich złożoność może w pewnym stopniu przybliżyć korespondencja związana z mediacją w sprawie rozwiązania Studia Levitt-Him. Zachowane $\mathrm{w}$ archiwum listy wymieniane między Himem a londyńskim radcą prawnym A. Appelbe wskazują, że symetria pozycji w spółce z biegiem lat uległa zaburzeniu, a dominujący Levitt zaczął z czasem traktować mniej pewnego siebie partnera jak wykonawcę zleceń, które sam pozyskiwał, jednocześnie poświęcając się malarstwu zamiast pracy na rzecz Studia. Pogorszenie się stosunków między artystami z biegiem lat doprowadziło ich do sytuacji, gdy w przypływie gniewu jeden podarł prace drugiego. Obraz ten, choć jednostronny, daje przykład, jaką dynamikę emocjonalną mogły mieć relacje między partnerami w takich spółkach. 
Podczas gdy Studio Levitt-Him powstało dosyć spontanicznie, inne spółki były raczej wynikiem wcześniejszej sympatii i wspólnych doświadczeń tworzących je partnerów. Artyści znali się zazwyczaj jeszcze ze studiów i często mieli okazję współpracować lub przynajmniej znali dobrze możliwości przyszłego wspólnika. Niekiedy okazjonalne zrazu współprace przeradzały się w trwalsze związki. Tak było zapewne w przypadku Lipińskiego i Rubinrota, którzy często pracowali razem w drugiej połowie lat trzydziestych. Dobre efekty tej kooperacji skłoniły ich do założenia spółki autorskiej, która niestety nie zdołała zaistnieć z powodu wybuchu wojny. Niekiedy tego rodzaju inicjatywy wchodziły w epizodyczne współprace z innymi artystami. Tandem Nowicki-Sandecka współpracował między innymi z Hryniewieckim i Bowbelskim, Girs i Barcz z kolei okazjonalnie współdziałali z Bolesławem Surałłą i Tadeuszem Kryszakiem. Warto wspomnieć także o ekskluzywnych oprawach dla ich druków, jakie powstawały w pracowni krakowskiego introligatora Roberta Jahody.

Spółki te od firm ujętych w następnej części oprócz bardziej partnerskich relacji między artystami odróżniał także stopień wewnętrznej organizacji. Zazwyczaj ich skład osobowy ograniczony był do samych partnerów, którzy nie zatrudniali do pomocy dodatkowych pracowników. Całość spraw studia oraz wykonanie projektów od początku do końca należały więc do artystów. Wiele wskazuje na to, że część z powstających w ramach tych spółek prac była de facto dziełami tylko jednego twórcy, sygnowanymi jedynie wspólnym logiem. Prace najdonioślejsze i najbardziej reprezentacyjne były jednak z pewnością efektem co najmniej kolektywnego wysiłku umysłowego, a niekiedy również wspólnego działania praktycznego. Jest to ciekawe zjawisko, które nie znajduje wielu analogii w innych gałęziach sztuk plastycznych. 
Tab. 2. Przedwojenne spółki autorskie

\begin{tabular}{|c|c|c|c|}
\hline $\begin{array}{c}\text { Lata } \\
\text { działalności }\end{array}$ & Nazwa spółki & Partnerzy & Dodatkowe informacje \\
\hline $1928-1939$ & $\begin{array}{l}\text { Osiecki- } \\
\text {-Skolimowski } \\
\text { (później jako } \\
\text { Spółka graficzna } \\
\text { Decor) }\end{array}$ & $\begin{array}{l}\text { Stefan Osiecki, } \\
\text { Jerzy Skolimow- } \\
\text { ski }\end{array}$ & $\begin{array}{l}\text { Tandem odnosił liczne sukcesy } \\
\text { w konkursach na plakat reklamowy. } \\
\text { Znane są także projekty okładek } \\
\text { książkowych. Artyści w czasie funk- } \\
\text { cjonowania spółki pracowali również } \\
\text { na własną rękę oraz podejmowali } \\
\text { inne, okazjonalne współprace. }\end{array}$ \\
\hline $1931-1944$ & $\begin{array}{l}\text { Atelier Girs- } \\
\text {-Barcz } \\
\text { (później jako } \\
\text { Oficyna War- } \\
\text { szawska) }\end{array}$ & $\begin{array}{l}\text { Anatol Girs, } \\
\text { Bolesław Barcz }\end{array}$ & $\begin{array}{l}\text { Spółka powstała w Warszawie } \\
\text { w } 1931 \text { roku i działała aż do śmierci } \\
\text { Barcza w } 1944 \text { roku. Od } 1938 \text { roku } \\
\text { znana jako Oficyna Warszawska. Po } \\
\text { wojnie Girs samodzielnie kontynu- } \\
\text { ował działalność pod szyldami Ofi- } \\
\text { cyna Warszawska na Obczyźnie oraz } \\
\text { Anatol Girs Press — najpierw w Mo- } \\
\text { nachium, od } 1947 \text { roku w Detroit, } \\
\text { a następnie od } 1969 \text { roku w West } \\
\text { Chesterfield (New Hampshire). } \\
\text { Artyści swoje najważniejsze projekty } \\
\text { wykonali dla Głównej Księgarni Woj- } \\
\text { skowej. Podejmowali też epizodycz- } \\
\text { ne współprace z R. Jahodą, B. Surałłą } \\
\text { i T. Kryszakiem. }\end{array}$ \\
\hline $1931-1939$ & $\begin{array}{l}\text { Pracownia deko- } \\
\text { racyjno-graficzna } \\
\text { M. Nowckiego } \\
\text { i S. Sandeckiej }\end{array}$ & $\begin{array}{l}\text { Maciej Nowicki, } \\
\text { Stanisława San- } \\
\text { decka-Nowicka }\end{array}$ & $\begin{array}{l}\text { Spółka powstała w Warszawie } \\
\text { w } 1931 \text { roku. W } 1938 \text { roku jej człon- } \\
\text { kowie zawarli małżeństwo. Po wojnie } \\
\text { pozostali na emigracji w USA, gdzie } \\
\text { wciąż okazjonalnie tworzyli razem } \\
\text { projekty graficzne i dekoracje. } \\
\text { Tandem ten odnosił liczne sukcesy } \\
\text { w konkursach na plakaty reklamowe. } \\
\text { Nowicki i Sandecka wykonywali } \\
\text { także projekty okładkowe i architek- } \\
\text { toniczne. } \\
\text { Jako spółka podejmowali również } \\
\text { epizodycznie współpracę z Bowbel- } \\
\text { skim i Hryniewieckim. }\end{array}$ \\
\hline $\begin{array}{l}\text { około } \\
1931-1938\end{array}$ & A. i F. Seifert & $\begin{array}{l}\text { Anna Birtus- } \\
\text {-Seifert, } \\
\text { Franciszek Seifert }\end{array}$ & $\begin{array}{l}\text { Kraków. Małżeństwo. } \\
\text { Działali przede wszystkim na polu } \\
\text { plakatu, reklamy, dekoratorstwa oraz } \\
\text { projektowania okładek. }\end{array}$ \\
\hline
\end{tabular}




\begin{tabular}{|c|c|c|c|}
\hline $1933-1936$ & $\begin{array}{l}\text { Spółka graficzna } \\
\text { Hryniewiecki } \\
\text { \& Osiecki (znana } \\
\text { też jako Pogoto- } \\
\text { wie Graficzne) }\end{array}$ & $\begin{array}{l}\text { Stefan Osiecki, } \\
\text { Jerzy Hryniewie- } \\
\text { cki }\end{array}$ & $\begin{array}{l}\text { Tandem odnosił liczne sukcesy } \\
\text { w konkursach na plakaty reklamowe. } \\
\text { Tworzyli także projekty okładek ksią- } \\
\text { żek i czasopism oraz stoisk i witryn } \\
\text { sklepowych. }\end{array}$ \\
\hline $1933-1954$ & $\begin{array}{l}\text { Studio Levitt-Him } \\
\text { (też jako Atelier } \\
\text { Levitt-Him; } \\
\text { po } 1937 \text { roku jako } \\
\text { Lewitt-Him) }\end{array}$ & $\begin{array}{l}\text { Jan Levitt (póź- } \\
\text { niej też jako Le- } \\
\text { witt lub Le Witt), } \\
\text { Jerzy Him (też } \\
\text { jako J. Himmel- } \\
\text { farb lub George } \\
\text { Him) }\end{array}$ & $\begin{array}{l}\text { Spółka założona w } 1933 \text { roku w War- } \\
\text { szawie, od } 1937 \text { roku działała w Lon- } \\
\text { dynie. } \\
\text { Jej rozpad nastąpił w } 1954 \text { roku. } \\
\text { Artyści w Polsce działali na polu } \\
\text { plakatu, reklamy, projektowali okład- } \\
\text { ki i ilustracje książkowe. Z czasem } \\
\text { rozszerzyli swoją działalność także } \\
\text { o prace przestrzenne i dekoracyjne, } \\
\text { wykonali nawet projekt mechanicznej } \\
\text { rzeźby-zegara dla firmy Guinness. }\end{array}$ \\
\hline $1933-1935$ & Atelier 33 & $\begin{array}{l}\text { Marek Żuławski, } \\
\text { Tadeusz Trep- } \\
\text { kowski }\end{array}$ & $\begin{array}{l}\text { Spółka została rozwiązana, gdy Żu- } \\
\text { ławski wyjechał do Paryża w } 1935 \\
\text { roku. Znane prace na polu reklamy } \\
\text { i plakatu. }\end{array}$ \\
\hline $\begin{array}{l}1933- \\
1937 / 1938\end{array}$ & $\begin{array}{l}\text { Atelier grafiki } \\
\text { dekoracyjno- } \\
\text {-reklamowej } \\
\text { Mewa }\end{array}$ & $\begin{array}{l}\text { Antoni Wajwód, } \\
\text { Edward Manteu- } \\
\text { fell, } \\
\text { Jadwiga Hładki- } \\
\text {-Wajwódowa }\end{array}$ & $\begin{array}{l}\text { Atelier założyli A. Wajwód i E. Man- } \\
\text { teufell. J. Hładki i Wajwód byli } \\
\text { małżeństwem. Atelier znane było } \\
\text { szczególnie dzięki doskonałym } \\
\text { okładkom książek i czasopism, pla- } \\
\text { katom i aranżacji witryn oraz pracom } \\
\text { papieroplastycznym. }\end{array}$ \\
\hline $1934-1935$ & Atelier AGAR & $\begin{array}{l}\text { Bolesław Surałło, } \\
\text { Edmund Ernest- } \\
\text {-Kosmowski }\end{array}$ & $\begin{array}{l}\text { Niektóre źródła podają błędnie jako } \\
\text { rok założenia 1937. Wykonywali } \\
\text { projekty reklamowe oraz okładki } \\
\text { książek i czasopism. Liczne prace dla } \\
\text { Ligi Morskiej i Kolonialnej. W } 1934 \\
\text { roku I nagroda w konkursie na plakat } \\
\text { z okazji Dnia Polaka z Zagranicy. } \\
\text { Niektóre prace sygnowane jako } \\
\text { „Surałło-Kosmowski”. }\end{array}$ \\
\hline 1936-1939 & Lipiński-Rubinrot & $\begin{array}{l}\text { Andrzej Rubinrot, } \\
\text { Eryk Lipiński }\end{array}$ & $\begin{array}{l}\text { Znanych kilka wspólnych okładek, } \\
\text { przede wszystkim dla wydawnictwa } \\
\text { Renaissance. Początkowo współpraca } \\
\text { artystów nie miała charakteru sforma- } \\
\text { lizowanego, jednak, jak wspominał } \\
\text { Lipiński, planowali założyć wspólne } \\
\text { atelier. Plany te pokrzyżował wybuch } \\
\text { wojny. } \\
\text { Wspólne prace sygnowane ,andr-erl”. }\end{array}$ \\
\hline
\end{tabular}




\begin{tabular}{|c|c|c|c|}
\hline $\begin{array}{l}\text { około } \\
1938-1939\end{array}$ & $\begin{array}{l}\text { Atelier J. i M. } \\
\text { Leopoldstadt }\end{array}$ & $\begin{array}{l}\text { J. i M. Leopold- } \\
\text { stadtowie }\end{array}$ & $\begin{array}{l}\text { Warszawa/Lwów? Zapewne małżeń- } \\
\text { stwo lub rodzeństwo. Znane jedynie } \\
\text { kilka prac: reklamy farmaceutyczne } \\
\text { oraz okładki dla Księgarni Popularnej } \\
\text { w Warszawie. Atelier związane było } \\
\text { prawdopodobnie z dość enigma- } \\
\text { tyczną postacią lwowskiego malarza } \\
\text { o nazwisku Leopoldstadt, który wy- } \\
\text { konywał między innymi dekoracje } \\
\text { dla Opery Lwowskiej. }\end{array}$ \\
\hline
\end{tabular}

\section{STUDIA I DZIAŁY GRAFICZNE}

Do tej kategorii spółek zaliczono pozostałe firmy świadczące usługi na rynku graficznym. Grupa ta jest bardzo różnorodna, a poszczególne przedstawione tu podmioty często różniły się od siebie pod wieloma względami. Zostały one zestawione zbiorczo, aby ukazać ich odrębność w stosunku do wcześniej zaprezentowanych spółek autorskich i partnerstw epizodycznych. Bardziej szczegółowy podział jest trudny do ustalenia $\mathrm{z}$ uwagi na często ograniczone informacje na temat ich funkcjonowania.

Ta forma działalności pojawiła się dość wcześnie, wraz ze wzrostem zapotrzebowania na usługi graficzne, których nie były już w stanie zaspokoić warsztaty nawet najwprawniejszych zecerów. Część z nich była autonomicznymi firmami, założonymi w celu realizacji usług graficznych, zaś niektóre podjęły tego rodzaju usługi na drodze ewolucji od innego rodzaju zarobkowania, na przykład produkcji pocztówek czy litografii artystycznej. Nierzadko studia graficzne działały też jako przybudówki większych przedsiębiorstw, najczęściej dobrze prosperujących zakładów graficznych czy dużych agencji reklamowych i ogłoszeniowych, jak Polska Agencja Telegraficzna, Agencja Wschodnia czy Reklama Pocztowa. Niektóre z tych firm, na przykład wspomniana trójka, były spółkami państwowymi lub subsydiowanymi w dużym stopniu z finansów publicznych. Jeszcze mocniej powiązane z działalnością władz były Państwowe Zakłady Graficzne, przekształcone później w Polską Wytwórnię Papierów Wartościowych. Przeważająca większość studiów była jednak własnością prywatną lub częścią przedsiębiorstw prywatnych.

Założycielami firm działających jako samodzielnie studia graficzne byli najczęściej doświadczeni i posiadający zmysł biznesowy artyści, jak T. Gronowski, J.E. Mucharski, H. Berlewi, Emil Lindemann czy Stanisław Geniusz (ten ostatni w Katowicach). Powstawały również studia opierające się na autorytecie ich właściciela, będącego jednocześnie głównym grafikiem. Taki charakter miały najpewniej Biuro Lu-Can E. Kazubskiego czy Atelier J. Hartman. Niestety nie wiadomo, 
na jak dużą skalę działały te firmy, i czy nie były one podmiotami jednoosobowymi. Artyści zakładający tego typu firmy częstokroć wchodzili w spółki nie tylko z innymi grafikami. Jednym z założycieli świetnie prosperującego Atelier Plakat był A. Borman, a do spółki Reklama-Mechano z H. Berlewim przystąpili S. Brucz i A. Wat. Reklamą Pocztową kierował Melchior Wańkowicz, a Atelier Pro-pressa założył z kolei publicysta i wydawca Bolesław Szczepkowski.

Studia-przybudówki dużych zakładów i przedsiębiorstw powstawały najczęściej dzięki właścicielom tych spółek, którzy dostrzegali w nich szansę na zwiększenie potencjału swoich firm. Zmieniający się z czasem charakter działalności niektórych z nich wymuszał wręcz powstanie osobnych działów zajmujących się projektowaniem graficznym. Kierownictwo takich studiów powierzano najczęściej artystom mającym doświadczenie zarówno w zakresie projektowania, jak i organizacji podobnych przedsięwzięć. T. Gronowski pracował przez lata jako dyrektor artystyczny biur graficznych działających przy Litografii Artystycznej W. Główczewskiego, Zakładach graficznych B. Wierzbicki i s-ka oraz Zakładach Braci Koziańskich. Wszystkie z wymienionych spółek należały do czołowych warszawskich zakładów graficznych. Atelier graficznym Polskiego Towarzystwa Księgarń Kolejowych Ruch kierowali z kolei J.E. Mucharski, K. Mann i T. Kryszak.

Niestety wciąż niewiele wiadomo na temat organizacyjnej strony działalności wielu spośród tych firm. Ich pełny skład osobowy pozostaje zazwyczaj nieznany. Można jednak domniemywać, że studia te miały bardziej rozbudowaną strukturę organizacyjną niż spółki autorskie. Wiadomo, że Atelier Grafik zatrudniało sześć-siedem osób (Łącka, 1963). Zakłady Graficzne i Poradnia Reklamy Linia i Litera Jerzy Bursztyn i Ska miały przed wojną ponad tuzin pracowników, jednak byli to nie tylko graficy, ale również pracownicy administracyjni i obsługa warsztatu. W przypadku studiów-przybudówek większych przedsiębiorstw były one częścią struktur podlegających także właścicielom czy kierownictwu całej firmy.

Niełatwe do odtworzenia są również relacje tych przedsiębiorstw z zatrudnianymi artystami. Ci najbardziej rozchwytywani zajmowali lukratywne stanowiska kierownicze i mogli zapewne cieszyć się dużą autonomią w ramach pracy studyjnej oraz realnym wpływem na decyzje zapadające w firmie. Mniej doświadczeni twórcy pracowali jednak zazwyczaj w roli wyrobników. Ich oddziaływanie na dobór realizowanych prac było zazwyczaj znikome, a niezależność w działaniu mocno ograniczona ze względu na wymagania stawiane przez klientów i kierownictwo studia. Jak wspominał A. Girs, który krótko pracował w Atelier Plakat, tempo pracy było duże, zarobki natomiast nie były zadowalające (Kłossowski, 1989). Znane są również przykłady, gdy firmy takie korzystały z usług niezależnych artystów, a nawet spółek autorskich, które angażowane były do wykonania konkretnych zleceń. 
Podobnie jak w przypadku wcześniej omawianych typów współpracy artystycznej, również w odniesieniu do studiów graficznych można zauważyć dużą rotację tych samych artystów. Wielu zaangażowanych w pracę takich przedsiębiorstw twórców wcześniej lub później uczestniczyło w innych typach kooperacji artystycznych. Artyści, dla których taka forma pracy wydawała się optymalna, niejednokrotnie migrowali też między studiami, zapewne w poszukiwaniu lepszych warunków zatrudnienia i ambitniejszych projektów. Najobrotniejsi mają na swoim koncie udział w kilku takich spółkach lub nawet ich założenie. Wyróżnia się tutaj oczywiście T. Gronowski, który już za swego życia uchodził za „,człowieka-instytucję", a lista rozmaitych jego spółek i inicjatyw jest bardzo długa. Dużą mobilnością wykazywał się też J.E. Mucharski, który należał do założycieli Atelier Plakat i Atelier Ara, współpracował też w międzyczasie z Agencją Grafik, by w końcu objąć kierownictwo artystyczne Atelier Graficznego Ruch. Jako współwłaściciele lub pracownicy co najmniej dwóch studiów wymieniani są również: J. Levitt, E. John, Ryszard Biské oraz J. Hartman.

Kolejnym w dużej mierze niezbadanym obszarem jest finansowy wymiar działalności tych spółek. Ich z reguły długa obecność na rynku oraz rosnąca liczba podobnych inicjatyw świadczą, że musiały być to przedsięwzięcia opłacalne. Mnogość realizowanych zleceń przekładała się z pewnością na spore dochody. Nie bez wpływu na ten aspekt działalności pozostawała także $\mathrm{z}$ pewnością renoma studia czy związanych z nim znanych artystów. T. Gronowski, który był w międzywojniu jednym z najbardziej wziętych grafików reklamowych, dzięki udziałowi w kilku takich inicjatywach dorobił się niemałej fortuny. Jego zarobki w latach trzydziestych szokowały i były powodem zazdrości ze strony wielu gorzej prosperujących grafików (Szablowska, 2005). Połączenie przez Gronowskiego talentu artystycznego z wyczuciem biznesowym można traktować jako pewien wzorzec, do którego dążyło zapewne wielu twórców kolejnego pokolenia.

Studia graficzne pozyskiwały zlecenia w rozmaity sposób. Niekiedy ich działalność napędzało zapotrzebowanie wytwarzane przez firmę-matkę - zakład graficzny, agencję prasową czy biuro ogłoszeniowo-reklamowe. Inne działały jednak na wolnym rynku i same reklamowały swe usługi w prasie, informatorach czy na łamach branżowych pism, jak „Reklama” czy „Rocznik Polskiej Grafiki Reklamowej”. Bardzo często studia te podejmowały stałą współpracę, zwłaszcza z dużymi podmiotami. Atelier Ruch przez wiele lat miało monopol na usługi graficzne dla przedsiębiorstwa Poczta Polska, Telegraf i Telefon. Inne tego typu podmioty często wiązały swoją działalność z dużymi monopolami państwowymi czy zakładami przemysłowymi, choć przedsiębiorstwa te równie chętnie korzystały z usług spółek autorskich oraz artystów działających na własną rękę (o ile należeli do KAGR). Kluczową rolę przy pozyskiwaniu zleceń odgrywały również kwestie relacji osobistych, znajomości i zaufania do renomy studia czy związanych z nim artystów. 
Jedną z technik budowania firmowej marki było stosowanie przez tego typu firmy sygnatur, czasem przywodzących na myśl drukarskie sygnety. Miały one nieco inną formę niż standardowe sygnatury autorskie i przypominały z reguły znaki graficzne, choć zazwyczaj wpisywano je w prace odręcznie. Takie charakterystyczne podpisy obserwować można na pracach Atelier Plakat, Atelier Ruch, Atelier Grafik czy Wytwórni Fama. Niekiedy obok sygnatury studia widniał także podpis artysty, który wykonał pracę. Bardzo często pozostawał on jednak anonimowy.

Opracowania na temat działalności oraz charakteru większości przedstawionych spółek są bardzo nieliczne. Najczęściej lata ich działalności znane są jedynie w przybliżeniu, a składy osobowe wielu z nich wciąż pozostają nieustalone. $Z$ tego powodu trzeba zasygnalizować potrzebę pogłębionych badań archiwalnych i źródłowych oraz zgromadzenia pełniejszego wykazu wytworów omawianych spółek. W zamieszczonym tutaj zestawieniu znalazło się kilka firm, o których wiadomo bardzo niewiele. Nie ustalono więc z całą pewnością, czy Atelier DKB było $\mathrm{w}$ istocie studiem graficznym, czy miało raczej charakter spółki autorskiej.

W sumie w tabeli ujęto 28 podmiotów. Pierwsze studia graficzne rozwinęły się najwcześniej, jeszcze w drugiej dekadzie XX wieku, przy warszawskich Zakładach Graficznych B. Wierzbickiego i Litografii W. Główczewskiego oraz krakowskim Salonie Malarzy Polskich Henryka Frista. Jednak okres najbardziej intensywnego rozwoju tego typu działalności przypadł przede wszystkim na lata dwudzieste i trzydzieste. Pracownie takie, choć najwięcej spośród nich funkcjonowało w Warszawie, powstawały także w innych dużych ośrodkach miejskich Rzeczypospolitej: Lwowie, Katowicach oraz Poznaniu. Informacje takie odnotowano w kolumnie uwag. Warto zwrócić też uwagę, że okres działalności samego studia graficznego nie zawsze pokrywa się z latami funkcjonowania przedsiębiorstwa, którego było częścią.

W tabeli starano się w miarę możliwości podać informacje na temat osób związanych ze studiami oraz roli, jaką w nich pełniły. Niestety z powodu braków w źródłach i opracowaniach biograficznych poszczególnych twórców wykaz ten nie jest w pełni kompletny. Mimo to zdecydowano się na publikację zgromadzonych informacji, gdyż mogą być one pomocne przy dalszych badaniach. 
Tab. 3. Przedwojenne studia i działy graficzne

\begin{tabular}{|c|c|c|c|}
\hline $\begin{array}{c}\text { Lata } \\
\text { działalności }\end{array}$ & Nazwa studia & Powiązane osoby & Dodatkowe informacje \\
\hline $\begin{array}{l}\text { około } \\
1920-1944\end{array}$ & $\begin{array}{l}\text { Salon Malarzy } \\
\text { Polskich Henryk } \\
\text { Frist i spółka } \\
\text { (też jako Wydaw- } \\
\text { nictwo Salonu } \\
\text { Malarzy Polskich } \\
\text { Henryk Frist } \\
\text { i ska) }\end{array}$ & $\begin{array}{l}\text { Właściciele: } \\
\text { Henryk Frist (założy- } \\
\text { ciel; 1882-1920) } \\
\text { Juliusz i Józef Frist } \\
\text { (1920-1939) } \\
\text { Współ- } \\
\text { pracownicy: } \\
\text { Juliusz Kossak, } \\
\text { Wojciech Kossak, } \\
\text { Jerzy Kossak, } \\
\text { Stanisław Tondos }\end{array}$ & $\begin{array}{l}\text { Firma działająca od } 1882 \text { roku } \\
\text { w Krakowie, specjalizowała się } \\
\text { początkowo w handlu dziełami } \\
\text { sztuki oraz produkcji kart pocz- } \\
\text { towych, jednak z czasem roz- } \\
\text { winęła działalność jako studio } \\
\text { dekoratorsko-graficzne; w póź- } \\
\text { niejszym czasie prowadziła } \\
\text { także samodzielną działalność } \\
\text { wydawniczą. Jedną z jej przy- } \\
\text { budówek były Zakłady Gra- } \\
\text { ficzne Akropol. Jej działalność } \\
\text { o grafikę reklamową poszerzyli } \\
\text { zapewne J i J. Fristowie po } \\
1920 \text { roku. }\end{array}$ \\
\hline $\begin{array}{l}\text { około } \\
1917-1945\end{array}$ & $\begin{array}{l}\text { Studio graficz- } \\
\text { ne Litografii } \\
\text { Artystycznej } \\
\text { W. Główczewski }\end{array}$ & $\begin{array}{l}\text { Właściciel zakładów: } \\
\text { Kazimierz Główczewski } \\
\text { Kierownik artystyczny: } \\
\text { Tadeusz Gronowski } \\
\text { (1917-1927) } \\
\text { Współpracownicy: } \\
\text { Edmund Bartłomiejczyk, } \\
\text { Ludwik Gardowski, } \\
\text { Jerzy Gelbard, } \\
\text { Edmund John, } \\
\text { Zygmunt Kamiński, } \\
\text { Stefan Norblin, } \\
\text { Władysław Skoczylas }\end{array}$ & $\begin{array}{l}\text { Zakłady litograficzne działały } \\
\text { w latach 1877-1945. Wy- } \\
\text { odrębnione studio graficzne } \\
\text { uruchomiono około } 1917 \text { roku. } \\
\text { Projektowało druki reklamowe, } \\
\text { plakaty i okładki. }\end{array}$ \\
\hline $\begin{array}{l}\text { około } \\
1918-1944\end{array}$ & $\begin{array}{l}\text { Pracownia rysun- } \\
\text { ku przy Zakła- } \\
\text { dach graficznych } \\
\text { B. Wierzbicki } \\
\text { i s-ka }\end{array}$ & $\begin{array}{l}\text { Założyciel zakładów: } \\
\text { Bolesław Wierzbicki } \\
\text { Kierownik zakładów: } \\
\text { Tadeusz Gronowski } \\
\text { (1918-1939) } \\
\text { Kierownik pracowni } \\
\text { rysunku: } \\
\text { Ryszard Kleczewski } \\
\text { (1921) } \\
\text { Współpracownicy: } \\
\text { Adam Półtawski }\end{array}$ & $\begin{array}{l}\text { Zakłady graficzne działały } \\
\text { w latach } 1897-1944 \text {. Osobny } \\
\text { dział graficzny uruchomiony } \\
\text { został prawdopodobnie około } \\
1918 \text { roku. Studio wykonywało } \\
\text { projekty publikacji, okładek } \\
\text { i druków ulotnych. }\end{array}$ \\
\hline
\end{tabular}




\begin{tabular}{|c|c|c|c|}
\hline $\begin{array}{l}\text { około } \\
1919-1926\end{array}$ & $\begin{array}{l}\text { Dział artystyczny } \\
\text { Państwowych } \\
\text { Zakładów Gra- } \\
\text { ficznych }\end{array}$ & $\begin{array}{l}\text { Pracownicy: } \\
\text { Ryszard Kleczewski } \\
\text { (od 1921) }\end{array}$ & $\begin{array}{l}\text { PZG oprócz własnego zaplecza } \\
\text { drukarskiego posiadały także } \\
\text { liczne działy pomocnicze: lito- } \\
\text { grafii, chemigrafii, farbiarnię, } \\
\text { dział artystyczny oraz stację } \\
\text { doświadczalną. W } 1926 \text { roku } \\
\text { studio projektowało przede } \\
\text { wszystkim banknoty, papiery } \\
\text { wartościowe i druki państwowe. } \\
\text { W tym samym roku PZG prze- } \\
\text { kształcono w Polską Wytwórnię } \\
\text { Papierów Wartościowych. }\end{array}$ \\
\hline $\begin{array}{l}\text { 1921-1925 } \\
\text { lub później }\end{array}$ & $\begin{array}{l}\text { Biuro projektowo- } \\
\text {-rysunkowe } \\
\text { Lu-Can }\end{array}$ & $\begin{array}{l}\text { Założyciel: } \\
\text { Edward Kazubski }\end{array}$ & $\begin{array}{l}\text { Lwów/Warszawa? } \\
\text { Pod pseudonimem i sygnaturą } \\
\text { Lu-Can występował także sam } \\
\text { Kazubski. Znane są przede } \\
\text { wszystkim projekty okładek dla } \\
\text { wydawnictwa Ateneum, rekla- } \\
\text { my dla firmy J.A. Baczewski } \\
\text { oraz prace plakatowe. }\end{array}$ \\
\hline $1923-1926$ & $\begin{array}{l}\text { Atelier reklamy } \\
\text { artystycznej } \\
\text { Plakat }\end{array}$ & $\begin{array}{l}\text { Założyciele: } \\
\text { Tadeusz Gronowski, } \\
\text { Antoni Borman, } \\
\text { Jerzy Gelbard, } \\
\text { Jan Mucharski, } \\
\text { Pracownicy: } \\
\text { Anatol Girs }\end{array}$ & $\begin{array}{l}\text { Studio specjalizowało się } \\
\text { w pracach reklamowych, } \\
\text { szczególnie plakacie oraz } \\
\text { projektowaniu okładek. Około } \\
1926 \text { roku Atelier Plakat opuś- } \\
\text { cił Gronowski. W tym czasie } \\
\text { Borman wraz z Mucharskim } \\
\text { na bazie dotychczasowej firmy } \\
\text { utworzyli Atelier Ara. }\end{array}$ \\
\hline $\begin{array}{l}1923- \\
1924 ?\end{array}$ & $\begin{array}{l}\text { Dekoracja Wnętrz } \\
\text { Projektowanie } \\
\text { i Wykonywanie } \\
\text { Rysunków z Za- } \\
\text { kresu Grafiki Sto- } \\
\text { sowanej R. Biské, } \\
\text { J. Sosnkowski } \\
\text { i Ska }\end{array}$ & $\begin{array}{l}\text { Właściciele: } \\
\text { Bolesław Wierzbicki, } \\
\text { Ryszard Biské, } \\
\text { Jerzy Sosnkowski }\end{array}$ & $\begin{array}{l}\text { Studio wykonywało prace } \\
\text { dekoratorskie i reklamowe. }\end{array}$ \\
\hline
\end{tabular}




\begin{tabular}{|c|c|c|c|}
\hline $\begin{array}{l}\text { 1924-1925 } \\
\text { lub później }\end{array}$ & $\begin{array}{l}\text { Studio reklamowe } \\
\text { Reklama- } \\
\text {-Mechano }\end{array}$ & $\begin{array}{l}\text { Założyciele: } \\
\text { Henryk Berlewi, } \\
\text { Stanisław Brucz, } \\
\text { Aleksander Wat }\end{array}$ & $\begin{array}{l}\text { Studio świadczyło usługi nie } \\
\text { tylko w zakresie grafiki użyt- } \\
\text { kowej, ale również komplekso- } \\
\text { wego przygotowania reklamy. } \\
\text { Wszystkie druki projektowane } \\
\text { były w duchu autorskiej kon- } \\
\text { cepcji Berlewiego - mecha- } \\
\text { nofaktury. Przedsiębiorstwo } \\
\text { wykonywało projekty okładek, } \\
\text { plakatów, prospektów reklamo- } \\
\text { wych i neonów. }\end{array}$ \\
\hline $\begin{array}{l}\text { około } \\
1924-?\end{array}$ & $\begin{array}{l}\text { Instytut Propa- } \\
\text { gandy Nowoczes- } \\
\text { nej Energja }\end{array}$ & $\begin{array}{l}\text { Założyciel: } \\
\text { Tadeusz Hoffmann }\end{array}$ & $\begin{array}{l}\text { Poznań. } \\
\text { Firma działała jako biuro rekla- } \\
\text { my i studio graficzne. Ofero- } \\
\text { wała kompleksowe przygoto- } \\
\text { wanie kampanii reklamowych, } \\
\text { opracowanie graficzne druków, } \\
\text { a nawet przygotowanie klisz. }\end{array}$ \\
\hline $\begin{array}{l}\text { około } \\
1924-?\end{array}$ & $\begin{array}{l}\text { Agencja Rekla- } \\
\text { mowa Decor }\end{array}$ & $\begin{array}{l}\text { Założyciele: } \\
\text { Ryszard Biské } \\
\text { Edmund John } \\
\text { Współpracownicy: } \\
\text { Jerzy Sosnowski }\end{array}$ & $\begin{array}{l}\text { Prawdopodobnie firma zajęła } \\
\text { miejsce założonej nieco wcześ- } \\
\text { niej Dekoracji Wnętrz R. Biské } \\
\text { i J. Sosnowski. Agencja projek- } \\
\text { towała reklamy oraz scenogra- } \\
\text { fie filmowe. }\end{array}$ \\
\hline $\begin{array}{l}\text { około } \\
1925-1930\end{array}$ & $\begin{array}{l}\text { Atelier Grafik } \\
\text { (też jako Agencja } \\
\text { Grafik) }\end{array}$ & $\begin{array}{l}\text { Założyciel: } \\
\text { Emil Lindemann, } \\
\text { Henryk Nowina Czerny } \\
\text { (prawdopodobnie jako } \\
\text { partner) } \\
\text { Pracownicy: } \\
\text { Wacław Siemiątkowski } \\
\text { Leon Chejfec, } \\
\text { Jan Levitt, } \\
\text { Jan Mucharski }\end{array}$ & $\begin{array}{l}\text { M. Łącka jako rok założenia } \\
\text { wskazuje } 1928 . \\
\text { Autorka ta odnotowała też, } \\
\text { że studio zatrudniało sześć- } \\
\text { siedem osób. Atelier wykony- } \\
\text { wało projekty reklamowe, zna- } \\
\text { ne są między innymi prace dla } \\
\text { przemysłu cukrowniczego. }\end{array}$ \\
\hline $1926-1930$ & $\begin{array}{l}\text { Atelier Reklamy } \\
\text { Artystycznej Ara }\end{array}$ & $\begin{array}{l}\text { Założyciele: } \\
\text { Antoni Borman, } \\
\text { Jan Mucharski } \\
\text { Pracownicy: } \\
\text { C. i G. Nagabczyńscy }\end{array}$ & $\begin{array}{l}\text { Firma powstała z przekształce- } \\
\text { nia Atelier Plakat po odejściu } \\
\text { T. Gronowskiego w } 1926 \text { roku. } \\
\text { Wykonywała prace reklamowe } \\
\text { oraz projekty neonów dla } \\
\text { Lumineonu. }\end{array}$ \\
\hline
\end{tabular}




\begin{tabular}{|c|c|c|c|}
\hline 1926-1939 & $\begin{array}{l}\text { Dział artystyczny } \\
\text { Polskiej Wytwór- } \\
\text { ni Papierów War- } \\
\text { tościowych }\end{array}$ & $\begin{array}{l}\text { Kierownik działu: } \\
\text { Ryszard Kleczewski } \\
\text { (1928-1939) } \\
\text { Pracownicy: } \\
\text { Juliusz Kulesza } \\
\text { (jako praktykant } \\
\text { od } 1926 \text { roku) }\end{array}$ & $\begin{array}{l}\text { PWPW powstała z przekształ- } \\
\text { cenia Państwowych Zakładów } \\
\text { Graficznych, które również } \\
\text { posiadały własny dział graficz- } \\
\text { ny. Odpowiadał on za projek- } \\
\text { towanie graficzne banknotów, } \\
\text { papierów wartościowych i dru- } \\
\text { ków państwowych. }\end{array}$ \\
\hline $\begin{array}{l}\text { około } \\
1928 / 1929 \\
-1938\end{array}$ & $\begin{array}{l}\text { Atelier Graficzne } \\
\text { Ruch } \\
\text { (też jako Atelier } \\
\text { Reklamy Polskie- } \\
\text { go Towarzystwa } \\
\text { Księgarń Kolejo- } \\
\text { wych Ruch) }\end{array}$ & $\begin{array}{l}\text { Kierownicy: } \\
\text { Tadeusz Kryszak, } \\
\text { Jan Mucharski } \\
\text { (do } 1938 \text { roku), } \\
\text { Kazimierz Mann } \\
\text { (od } 1938 \text { roku) }\end{array}$ & $\begin{array}{l}\text { Do } 1933 \text { roku PTKK Ruch } \\
\text { posiadało monopol na pro- } \\
\text { mowanie usług państwowego } \\
\text { przedsiębiorstwa Poczta Polska, } \\
\text { Telegraf i Telefon. Atelier wy- } \\
\text { konywało przede wszystkim } \\
\text { prace reklamowe. }\end{array}$ \\
\hline $\begin{array}{l}\text { około } \\
1929-1939\end{array}$ & $\begin{array}{l}\text { Studio graficzne } \\
\text { przy Uniwersalnej } \\
\text { Agencji Rekla- } \\
\text { mowej }\end{array}$ & $\begin{array}{l}\text { Właściciele: } \\
\text { Zygmunt Goldwasser, } \\
\text { Leon Berkowicz }\end{array}$ & $\begin{array}{l}\text { Uniwersalna Agencja Reklamo- } \\
\text { wa pełniła rolę biura ogłoszeń, } \\
\text { jednak posiadała również włas- } \\
\text { ną manufakturę farb, litografię } \\
\text { oraz udziały w Zakładach } \\
\text { Graficznych Grafot i Chemi- } \\
\text { ka. Przy Agencji działało też } \\
\text { w latach trzydziestych studio } \\
\text { graficzne specjalizujące się } \\
\text { w pracach reklamowych. }\end{array}$ \\
\hline $\begin{array}{l}\text { około } \\
1930-?\end{array}$ & $\begin{array}{l}\text { Studio działające } \\
\text { przy Agencji } \\
\text { Wschodniej }\end{array}$ & - & $\begin{array}{l}\text { AW, podobnie jak PAT, pełniła } \\
\text { rolę agencji prasowo-ogłosze- } \\
\text { niowej. Była firmą prywatną, } \\
\text { jednak subsydiowaną ze środ- } \\
\text { ków państwowych. } \\
\text { Nie wiadomo dokładnie, kiedy } \\
\text { w jej strukturach powstał osob- } \\
\text { ny dział graficzny. }\end{array}$ \\
\hline $\begin{array}{l}\text { około } \\
1930-1939\end{array}$ & $\begin{array}{l}\text { Atelier Graficzne } \\
\text { Zakładów Gra- } \\
\text { ficznych Braci } \\
\text { Koziańskich }\end{array}$ & $\begin{array}{l}\text { Właściciele: } \\
\text { Eugeniusz Koziański, } \\
\text { Kazimierz Koziański } \\
\text { Kierownik artystyczny: } \\
\text { T. Gronowski } \\
\text { (1930-1935) } \\
\text { Współpracownicy: } \\
\text { Wacław Borowski, } \\
\text { Marek Żuławski, } \\
\text { Edward Dudziński, } \\
\text { J. Hartman }\end{array}$ & $\begin{array}{l}\text { Atelier działało przy Zakła- } \\
\text { dach Graficznych Eugeniusza } \\
\text { i Kazimierza Koziańskich. } \\
\text { W } 1919 \text { roku wykupili oni } \\
\text { upadłą drukarnię rodziny } \\
\text { Orgelbrandów w Warszawie, } \\
\text { rozszerzając swoją działalność, } \\
\text { prowadzoną dotąd w Krakowie. } \\
\text { Atelier graficzne wyodrębnione } \\
\text { zostało zapewne około 1930 } \\
\text { roku i funkcjonowało prawdo- } \\
\text { podobnie przy warszawskiej } \\
\text { filii firmy. }\end{array}$ \\
\hline
\end{tabular}




\begin{tabular}{|c|c|c|c|}
\hline $\begin{array}{l}\text { około } \\
\text { 1932-1945 } \\
\text { lub później }\end{array}$ & $\begin{array}{l}\text { Atelier Grafiki } \\
\text { i Malarstwa Re- } \\
\text { klamowego St. } \\
\text { Geniusz } \\
\text { (po wojnie jako } \\
\text { St. Geniusz i syn) }\end{array}$ & $\begin{array}{l}\text { Założyciel: } \\
\text { Stanisław Geniusz } \\
\text { Pracownicy: } \\
\text { Janusz Woźniakowski? }\end{array}$ & $\begin{array}{l}\text { Katowice. } \\
\text { Atelier specjalizowało się } \\
\text { w pracach reklamowych, wy- } \\
\text { konywało szyldy, liternictwo, } \\
\text { projekty opakowań, ilustracje } \\
\text { i dekoracje. }\end{array}$ \\
\hline $\begin{array}{l}\text { około } \\
1933-1939\end{array}$ & $\begin{array}{l}\text { Biuro graficzne } \\
\text { przedsiębiorstwa } \\
\text { Reklama Pocz- } \\
\text { towa }\end{array}$ & $\begin{array}{l}\text { Kierownicy: } \\
\text { Krzysztof Siedlecki } \\
\text { (1933-1936) } \\
\text { Melchior Wańkowicz } \\
\text { (1936-1939) } \\
\text { Pracownicy: } \\
\text { wiadomo, że agencja } \\
\text { korzystała z usług dzia- } \\
\text { łających na własną rękę } \\
\text { artystów (zwłaszcza } \\
\text { Mieczysława Bermana) } \\
\text { oraz innych studiów } \\
\text { graficznych (między } \\
\text { innymi Levitt-Him). }\end{array}$ & $\begin{array}{l}\text { Państwowa agencja reklamowa. } \\
\text { Przejęła od Atelier Ruch wy- } \\
\text { łączność na promowanie usług } \\
\text { PPTiT. Reklama Pocztowa była } \\
\text { też wydawcą pisma „Łącznik } \\
\text { Pocztowy”. }\end{array}$ \\
\hline $\begin{array}{l}\text { około } \\
1935-1939\end{array}$ & $\begin{array}{l}\text { Atelier grafiki } \\
\text { i dekoracji } \\
\text { Polskiej Agencji } \\
\text { Telegraficznej }\end{array}$ & $\begin{array}{l}\text { Kierownicy Atelier: } \\
\text { Henryk Mund } \\
\text { (1935-1936), } \\
\text { Kazimierz Mann } \\
\text { (od 1936/1938) } \\
\text { Pracownicy: } \\
\text { Kazimierz Mann, } \\
\text { Wanda Wernerowa, } \\
\text { Eugenia Różańska, } \\
\text { Stefan Osiecki }\end{array}$ & $\begin{array}{l}\text { Państwowa agencja prasowo- } \\
\text {-reklamowa. Atelier grafiki PAT } \\
\text { działało jako osobny wydział } \\
\text { podlegający biuru ogłoszeń } \\
\text { i reklam przy centrali PAT } \\
\text { w Warszawie. Pierwsze infor- } \\
\text { macje dotyczą objęcia kierow- } \\
\text { nictwa Atelier przez H. Munda. } \\
\text { Nie wiadomo, czy i w jakiej } \\
\text { formie istniało ono wcześniej. } \\
\text { Atelier projektowało materiały } \\
\text { reklamowe, plakaty, etykiety, } \\
\text { stoiska i dekoracje wystawowe, } \\
\text { aranżacje witryn i inne. }\end{array}$ \\
\hline $\begin{array}{l}\text { około } \\
\text { 1934-? }\end{array}$ & Biuro Plakat & - & $\begin{array}{l}\text { Lwów. Zapewne działało jako } \\
\text { biuro ogłoszeń połączone ze } \\
\text { studiem graficznym. }\end{array}$ \\
\hline $\begin{array}{l}\text { około } \\
1934-1936\end{array}$ & $\begin{array}{l}\text { Wytwórnia } \\
\text { Artystyczno- } \\
\text { Reklamowa Fama } \\
\text { inż. Kazimierz } \\
\text { Prószyński i Ska } \\
\text { (od } 1935 \text { roku } \\
\text { jako Atelier } \\
\text { Wnętrz i Archi- } \\
\text { tektury Pruszyń- } \\
\text { ski \& Magnuski) }\end{array}$ & $\begin{array}{l}\text { Właściciele: } \\
\text { Kazimierz Prószyński, } \\
\text { M. Sałabaj, } \\
\text { M. Nowak, } \\
\text { T. Magnuski } \\
\text { Pracownicy: } \\
\text { Wacław Machan }\end{array}$ & $\begin{array}{l}\text { Firma działała na polu reklamy, } \\
\text { projektowania plakatów, mebli, } \\
\text { dekoracji wnętrz oraz architek- } \\
\text { tury. }\end{array}$ \\
\hline
\end{tabular}




\begin{tabular}{|c|c|c|c|}
\hline 1934-? & $\begin{array}{l}\text { Projektowanie } \\
\text { Plakatów Rekla- } \\
\text { mowych i Pro- } \\
\text { pagandowych } \\
\text { Makowiecki \& } \\
\text { Maniecki }\end{array}$ & $\begin{array}{l}\text { Właściciele: } \\
\text { A. Maniecki, } \\
\text { L. Makowiecki }\end{array}$ & $\begin{array}{l}\text { Firma specjalizowała się w pro- } \\
\text { jektowaniu plakatów i druków } \\
\text { reklamowych. }\end{array}$ \\
\hline $\begin{array}{l}\text { około } \\
1935-1939\end{array}$ & $\begin{array}{l}\text { Atelier } \\
\text { J. Hartman }\end{array}$ & $\begin{array}{l}\text { Założyciel: } \\
\text { J. Hartman }\end{array}$ & $\begin{array}{l}\text { Jedyna odnaleziona wzmianka } \\
\text { o Atelier pochodzi z okolic } \\
\text { 1938/1939 roku, jednak wia- } \\
\text { domo, że J. Hartman działał } \\
\text { już wcześniej (między innymi } \\
\text { w studiu Zakładów Braci Ko- } \\
\text { ziańskich). Atelier reklamowało } \\
\text { usługi w zakresie grafiki, retu- } \\
\text { szu i druku na szkle. }\end{array}$ \\
\hline $\begin{array}{l}\text { około } \\
1936-?\end{array}$ & $\begin{array}{l}\text { Atelier dkb } \\
\text { (też jako Atelier } \\
\text { D. K. B.) }\end{array}$ & - & $\begin{array}{l}\text { Znane są projekty prospektów } \\
\text { reklamowych dla Fabryki Apa- } \\
\text { ratów Elektrycznych S. Kle- } \\
\text { iman i synowie. }\end{array}$ \\
\hline $\begin{array}{l}\text { około } \\
1937-1939\end{array}$ & $\begin{array}{l}\text { Atelier graficzne } \\
\text { Domu Prasy }\end{array}$ & $\begin{array}{l}\text { Pracownicy: } \\
\text { Maria Bilińska }\end{array}$ & $\begin{array}{l}\text { Dom Prasy był koncernem } \\
\text { prasowym działającym od } 1922 \\
\text { roku. Nie wiadomo dokładnie, } \\
\text { kiedy w jego ramach wyodręb- } \\
\text { nione zostało atelier graficzne. }\end{array}$ \\
\hline 1937-1943 & $\begin{array}{l}\text { Zakłady Gra- } \\
\text { ficzne i Poradnia } \\
\text { Reklamy Linia } \\
\text { i Litera Jerzy } \\
\text { Bursztyn i Ska }\end{array}$ & $\begin{array}{l}\text { Właściciele: } \\
\text { H.C. Morgensztern, } \\
\text { M.A. Fuks, } \\
\text { Michał Walersztain, } \\
\text { Jerzy Bursztyn } \\
\text { Pracownicy: } \\
\text { Dz. Wróblewska, Stani- } \\
\text { sław Glewiński. Roma- } \\
\text { na Holder (sekretariat) }\end{array}$ & $\begin{array}{l}\text { Przedsiębiorstwo zatrudniało } \\
\text { przed wojną ponad dwunastu } \\
\text { pracowników. } \\
\text { Znane są między innymi pro- } \\
\text { jekty reklamowe dla Orbisu. }\end{array}$ \\
\hline 1938-1939 & $\begin{array}{l}\text { Atelier grafiki } \\
\text { Polskiego Towa- } \\
\text { rzystwa Powier- } \\
\text { niczego dla prasy } \\
\text { i propagandy } \\
\text { Pro-Pressa }\end{array}$ & $\begin{array}{l}\text { Założyciel: } \\
\text { Bolesław Szczepkowski }\end{array}$ & $\begin{array}{l}\text { Atelier działało przy biurze } \\
\text { ogłoszeń Polskie Towarzystwo } \\
\text { Powiernicze dla prasy i propa- } \\
\text { gandy sp. z o.o., które prowa- } \\
\text { dziło działalność reklamową } \\
\text { i wydawniczą. }\end{array}$ \\
\hline
\end{tabular}

Mimo sporej liczby działających na rynku studiów oraz znaczących nazwisk, jakie powiązane były $\mathrm{z}$ wieloma $\mathrm{z}$ nich, firmy te nie zdominowały rynku przedwojennej sztuki użytkowej. Obok nich funkcjonowali z powodzeniem zarówno 
artyści działający na własną rękę, jak i mniejsze spółki autorskie. Podmioty te zazwyczaj z sobą konkurowały, niejednokrotnie wchodziły także w interakcje. Tworzyły się znajomości, nowe współprace i inicjatywy, a artyści niekiedy migrowali między firmami czy też zakładali własne. Przegląd tych powiązań, nawet tak powierzchowny, odsłania różnorodność i wielką dynamikę działalności sieci podmiotów świadczących usługi na polu sztuki użytkowej w przedwojennej Polsce.

\section{PO II WOJNIE ŚWIATOWEJ}

Większość z wymienionych tu spółek i studiów graficznych nie przetrwała wybuchu II wojny światowej oraz zmian, jakie nastąpiły po jej zakończeniu. Część dużych zakładów graficznych działała jeszcze po 1939 roku, jednak najczęściej pod narzuconym przez okupantów kierownictwem. Nie wiadomo, czy w ogóle i ewentualnie $\mathrm{w}$ jakim kształcie działały przy nich dawne działy graficzne.

W czasie wojny liczba polskich artystów pracujących na polu grafiki użytkowej została bardzo uszczuplona. Wielu z nich zginęło w trakcie działań wojennych bądź w obozach zagłady. Inni, posiadający stopnie oficerskie, trafiali do obozów jenieckich lub zostali zamordowani. Szczególnie narażeni byli twórcy o korzeniach żydowskich, którzy stanowili przed wojną spory odsetek warszawskich grafików.

Już w pierwszych dniach wojny, pod gruzami zbombardowanego magistratu w Lublinie, do którego eskortował płótno Bitwy pod Grunwaldem, zginął B. Surałło. W 1940 roku zamordowany został w Charkowie E. Menteuffel, zaliczany do ofiar zbrodni katyńskiej. W wyniku działań wojennych lub z ręki okupantów w kolejnych latach śmierć ponieśli Z. Glinicki, J. Gelbard, H. Jaworski. W czasie Powstania Warszawskiego zginęli B. Barcz, W. Jakimowicz, J. Hładki oraz jej mąż A. Wajwód. W latach wojny zmarli także Z. Gorski i S. Norblin, a tuż po wyzwoleniu przebywający w oflagu J. Alchimowicz.

Niektórym udało się przetrwać niespokojne lata wojny na emigracji. Większość z nich nigdy nie powróciła do kraju, choć część kontynuowała działalność artystyczną poza granicami. Niezachwianą ciągłość wspólnej działalności wskazać można chyba jedynie w przypadku Levitta i Hima, którzy już od 1937 roku przebywali w Londynie, gdzie mieszkali i tworzyli jeszcze wiele lat po wojnie. Do Londynu zawczasu wyjechał także M. Żuławski, który jednak już w tym czasie działał jedynie na własną rękę. Do fachu artystycznego z rożnym skutkiem starali się wracać również twórcy emigracyjni, opuszczający kraj w trakcie wojny lub bezpośrednio po niej. W Wielkiej Brytanii znaleźli się F. i S. Themersonowie, a w Stanach Zjednoczonych Ameryki działali M. Nowicki i S. Sandecka. A. Girs w pojedynkę reaktywował Oficynę Warszawską — najpierw w Monachium, a później w Detroit. Poza Polską pozostali również E. Ernest- 
-Kosmowski, W. Hryniewicz, T. Lipski, H. Mund, S. Osiecki, L. Piątkowski, T. Piotrowski i J. Skolimowski. Na emigracji w Hiszpanii, a potem w Chile z dużymi sukcesami działali z kolei Marian Rawicz i Maurycy Amster, którzy również okazjonalnie pracowali w duecie. Jednak $\mathrm{z}$ uwagi na brak udokumentowanych prac $\mathrm{w}$ Polsce nie uwzględniono ich w żadnym z powyższych zestawień.

Wiadomo o co najmniej kilku partnerstwach i spółkach zawiązywanych przez artystów w pierwszych latach powojennych i działających w latach czterdziestych, a nawet później. Inicjatywy takie podejmowali zarówno artyści aktywni jeszcze przed wojną, jak i twórcy nowego pokolenia. Świadczy to o wciąż utrzymującej się popularności modelu pracy kooperacyjnej, choć na nieporównywalnie mniejszą skalę niż w poprzedniej dekadzie. Co ciekawe, wyraźnie osłabło charakterystyczne dla okresu przedwojennego zainteresowanie spółek autorskich plakatem, który zastąpiły okładki i ilustracje książkowe. Wynikało to zapewne po części $\mathrm{z}$ marginalizacji sektora reklamowego w nowym ustroju polityczno-społecznym, jaki zapanował w powojennej Polsce.

Zestawienie otwiera tandem braci Zygmunta i Leopolda Haarów, którzy od 1943 roku pod kierownictwem S. Gliwy tworzyli prace graficzne na potrzeby wydawnictw II Korpusu Polskiego, stacjonującego wówczas w Rzymie. Pozostałe z wymienionych spółek i partnerstw działały w Warszawie.

Tab. 4. Partnerstwa artystyczne po II wojnie światowej

\begin{tabular}{|l|l|l|l|}
\hline $\begin{array}{c}\text { Lata } \\
\text { działalności }\end{array}$ & Typ współpracy & \multicolumn{1}{|c|}{ Partnerzy } & \multicolumn{1}{c|}{ Uwagi } \\
\hline $1943-1946$ & $\begin{array}{l}\text { Spółka autorska/ } \\
\text { partnerstwo } \\
\text { epizodyczne }\end{array}$ & $\begin{array}{l}\text { Zygmunt Haar, } \\
\text { Leopold Haar }\end{array}$ & $\begin{array}{l}\text { Z. i L. Haarowie byli braćmi. Działali } \\
\text { od II wojny światowej na emigracji } \\
\text { w Rzymie, opracowując graficznie } \\
\text { wydawnictwa II Korpusu Polskiego. } \\
\text { Znana jest jedna wspólnie sygnowa- } \\
\text { na okładka książkowa, plakaty oraz } \\
\text { projekt odznaki pamiątkowej. }\end{array}$ \\
\hline 1945 & $\begin{array}{l}\text { Partnerstwo } \\
\text { epizodyczne }\end{array}$ & $\begin{array}{l}\text { Tadeusz Trep- } \\
\text { kowski }\end{array}$ & Jedna praca plakatowa. \\
\hline $1946-1947$ & Spółka autorska & $\begin{array}{l}\text { Zdzisław Czacz- } \\
\text { ko, Antoni Święty }\end{array}$ & Znane projekty okładek. \\
\hline 1946 & $\begin{array}{l}\text { Partnerstwo } \\
\text { epizodyczne }\end{array}$ & $\begin{array}{l}\text { Jan Marcin } \\
\text { Szancer, } \\
\text { Anna Biernacka }\end{array}$ & $\begin{array}{l}\text { Znana jedna wspólnie zilustrowana } \\
\text { książka. }\end{array}$ \\
\hline
\end{tabular}




\begin{tabular}{|l|l|l|l|}
\hline $\begin{array}{l}1946 \\
\text { i } 1947\end{array}$ & $\begin{array}{l}\text { Partnerstwo } \\
\text { epizodyczne }\end{array}$ & $\begin{array}{l}\text { Anna Biernacka, } \\
\text { Wanda Werne- } \\
\text { rowa }\end{array}$ & $\begin{array}{l}\text { Znane dwie wspólnie ilustrowane } \\
\text { książki. }\end{array}$ \\
\hline $\begin{array}{l}\text { około } \\
1946-1947\end{array}$ & $\begin{array}{l}\text { Partnerstwo } \\
\text { w ramach studia } \\
\text { graficznego }\end{array}$ & $\begin{array}{l}\text { Szymon Bojko, } \\
\text { Witold Kalicki }\end{array}$ & $\begin{array}{l}\text { S. Bojko był kierownikiem działu } \\
\text { graficznego wydawnictwa Prasa Woj- } \\
\text { skowa, W. Kalicki był natomiast jego } \\
\text { pracownikiem. Wspólnie wykonali } \\
\text { liczne okładki książkowe i plakaty. }\end{array}$ \\
\hline 1946 & $\begin{array}{l}\text { Partnerstwo } \\
\text { epizodyczne }\end{array}$ & $\begin{array}{l}\text { Szymon Bojko, } \\
\text { Włodzimierz } \\
\text { Zakrzewski }\end{array}$ & $\begin{array}{l}\text { Znana jest jedna okładka, która } \\
\text { powstała zapewne w ramach pracy } \\
\text { Zakrzewskiego w studiu graficznym } \\
\text { wydawnictwa Prasa Wojskowa, któ- } \\
\text { rego kierownikiem był Bojko. }\end{array}$ \\
\hline $1948-1952$ & Spółka autorska & $\begin{array}{l}\text { Antoni Pucek, } \\
\text { Janina Grabska- } \\
\text {-Pucek }\end{array}$ & $\begin{array}{l}\text { Małżeństwo. } \\
\text { Działali na polu ilustracji książkowej. }\end{array}$ \\
\hline
\end{tabular}

W latach powojennych można zauważyć stopniowe wyhamowanie tendencji do zawiązywania spółek i tandemów autorskich, które, jak się zdaje, największą popularność zyskały w latach trzydziestych. Jak wspomniano na wstępie, zasięg chronologiczny przedstawionego zestawienia ogranicza się do pierwszej połowy XX wieku. Pobieżna analiza wskazuje jednak, że w latach pięćdziesiątych i później wyraźnie osłabło zainteresowanie artystów działalnością w kooperacjach według przedwojennego modelu. Zmienił się jednak również rynek sztuki użytkowej w Polsce - reklama ustąpiła pola propagandzie, z kolei swoboda artystycznego wyrazu ograniczona została przez sztywne ramy socrealizmu.

W sposób zbliżony do zorganizowanych studiów przedwojennych działały jedynie biura projektowe i działy graficzne będące częścią większych struktur, zazwyczaj znacjonalizowanych zakładów graficznych lub agencji wydawniczych. Ich zleceniodawcami były najczęściej instytucje i przedsiębiorstwa państwowe, które generowały w tym czasie największe zapotrzebowanie na reklamę i propagandę $\mathrm{w}$ formie graficznej. Jest to jednak odrębne zagadnienie, które należy rozpatrywać w zupełnie innych realiach gospodarczych, społecznych i politycznych. W takich przyzakładowych studiach graficznych wciąż zdarzały się jednak bliższe kooperacje między artystami. Przykładem mogą być tutaj prace S. Bojki, kierującego działem graficznym wydawnictwa Prasa Wojskowa, wykonane we współpracy z podwładnymi - W. Kalickim i W. Zakrzewskim.

Jak wynika z powyższych rozważań, zjawisko współpracy artystycznej na polu sztuki użytkowej w pierwszej połowie XX wieku stało się praktyką, która zyskała większą popularność, niż sądzono do tej pory. Na lata dwudzieste i trzydzieste przypadł szczytowy okres tej tendencji, która wyraźnie osłabła po wojnie. 
W latach późniejszych oczywiście można było spotkać, tak jak i dziś, twórcze tandemy, tria, grupy i kolektywy artystyczne działające na polu sztuki użytkowej, jednak nigdy nie osiągnęły one liczebności porównywalnej z podobnymi inicjatywami przedwojennymi. W drugiej połowie stulecia moda na spółki osłabła, choć nie znikła zupełnie. Rozszerzył się za to, jak można zauważyć, zakres działalności kreatywnej, w której ramach projektanci decydowali się na pracę w formie kolektywu. Jako przykłady warto wymienić łódzki tandem plakacistów, Bogusława Balickiego i Stanisława Łabęckiego (współpraca datowana od 1967 roku), oraz aktywność Romana Duszka i Andrzeja Zbrożka, którzy zrealizowali projekt identyfikacji wizualnej LOT-u w 1978 roku. Z zagranicy znany jest przykład współpracy Adriana Frutigera z Akirą Kobayashim przy tworzeniu krojów pism Frutiger Neue i Serif. Font Tahoma, na zlecenie firmy Microsoft, zaprojektowali z kolei wspólnie Matthew Carter i Tom Rickner (Kodzis, 2016). W Polsce od 2004 roku na polu projektowania krojów i identyfikacji wizualnych jako duet Fontarte działają Magdalena i Artur Frankowscy (Morka, 2014). Innym przykładem partnerstwa artystycznego (a także wydawniczego) może być łódzka grupa Correspondance des Arts, działająca od 1980 roku Wspólna praca wciąż jest popularna także wśród architektów, zwłaszcza w przypadku szczególnie wymagających i kompleksowych projektów. Dość dużą międzynarodową rozpoznawalność zdobyli między innymi hiszpański tandem Enrica Mirallesa i Benedetty Tagliabue (EMBT), Japończycy Kazuyo Sejima i Ryūe Nishizawa czy szwajcarskie biuro Jacques'a Herzoga i Pierre'a de Meuron. W Polsce podobne krótsze i dłuższe partnerstwa na polu architektury można obserwować z porównywalną intensywnością od lat pięćdziesiątych. Nikomu zapewne nie trzeba też bliżej przedstawiać słynnych tandemów świata mody - Domenica Dolcego i Stefano Gabbany czy nieco bliższych nam Marcina Paprockiego i Mariusza Brzozowskiego. Osobnym zagadnieniem, choć wyraźnie wpisującym się w zjawisko kooperacji artystycznej, są także kolektywy wspólnie tworzące graffiti, sztukę uliczną (na przykład monumentalne malarstwo na pociągach).

Choć zakres omawianego zjawiska przed wojną pozostawał do tej pory w niewielkim jedynie stopniu zbadany, już wcześniej dostrzegano rolę, jaką odegrały niektóre z opisanych spółek (Białostocki, 1963). Najpopularniejsze i najbardziej liczące się tandemy oraz tercety artystyczne, takie jak Atelier Mewa, Levitt-Him, Girs-Barcz, Sandecka-Nowicki, odniosły niemały sukces i śmiało mogły konkurować jakością oferowanych usług z dużymi studiami komercyjnymi. Dzięki swym oryginalnym pracom są one wzmiankowane w niemal każdej publikacji dotyczącej przedwojennej sztuki użytkowej. Być może z czasem coraz pełniejsze opracowanie źródeł archiwalnych i postępująca digitalizacja pozwolą bardziej szczegółowo odtworzyć losy tych spółek, które nie doczekały się jeszcze poważniejszych omówień. 


\section{BIBLIOGRAFIA}

Białostocki, J. (1963). Polska grafika użytkowa 1900-1939, próba charakterystyki. W: J. Starzyński (Red.), Z zagadnień plastyki polskiej w latach 1919-1939. Zbiór studiów. (ss. 171-206). Wrocław: Zakład Narodowy im. Ossolińskich - Wydawnictwo Polskiej Akademii Nauk.

Bojko, S. (1971). Polska sztuka plakatu, początki i rozwój do 1939 roku. Warszawa: Wydawnictwo Artystyczno-Graficzne.

Chmielewska, A. (1993). Atelier grafiki dekoracyjno-reklamowej „Mewa” (praca magisterska). Uniwersytet Warszawski.

Chmielewska, A. (1994). Atelier grafiki dekoracyjno-reklamowej „Mewa”. Ikonotheka, 8, 132-133.

Frankowski, A., Frankowska, M. (2009). Henryk Berlewi. Gdańsk: Pracownia.

Hölscher, E. (1936). Levitt Him, Warschau. Gebrauchsgraphik, Juli, 26-33.

Kaczorowski, J. (2017). Anatol Girs, Bolesław Barcz. W: J. Mrowczyk (Red.), Piękni XX-wieczni. Polscy projektanci graficy (ss. 112-119). Kraków: 2+3D.

Kaczorowski, J. (2020). Jan Levitt i Jerzy Him - życie i twórczość (praca doktorska). Uniwersytet Wrocławski.

Kłossowski, A. (1989). Anatol Girs — artysta ksiązki. Warszawa-Monachium-Detroit-West Chesterfield. Warszawa: Biblioteka Narodowa.

Kodzis, M. (2016). Projektowanie czytelności. Sztuka Edycji, 12, 57-64.

Łącka, M. (1963). Koło artystów grafików reklamowych. W: J. Starzyński (Red.), Ze studiów nad geneza plastyki nowoczesnej w Polsce. Zbiór studiów (ss. 317-396). Zakład Narodowy im. Ossolińskich - Wydawnictwo Polskiej Akademii Nauk.

Morka, A. (2014, 31 lipca). (Prze)krój polski: typografia nad Wisłą. https://culture.pl/pl/artykul/ przekroj-polski-typografia-nad-wisla.

Parszewska, D. (Red.). (2005). Architektura plakatu. Graficy-architekci z kręgu Politechniki Warszawskiej w latach 1915-1939. Warszawa: Muzeum Narodowe — Oddział Muzeum Plakatu w Wilanowie.

Rudziński, E. (1974). Sprawy ogłoszeniowe w działalności PZWDiC. Rocznik Historii Czasopiśmiennictwa, 14(1), 31-32.

Rypson, P. (1992). Ksiązki i strony. Polska książka awangardowa i artystyczna w XX wieku. Warszawa: Centrum Sztuki Współczesnej.

Rypson, P. (2017). Nie gęsi. Polskie projektowanie graficzne 1919-1949. Kraków: Wydawnictwo Karakter.

Smolik, P. (1935a). Hryniewiecki i Osiecki. Arkady, 1(7), 414-419.

Smolik, P. (1935b). Pracownia Graficzna M. Nowickiego i S. Sandeckiej. Arkady, 1(5), 287-293.

Smolik, P. (1935c). Pracownia graficzno-reklamowa „Mewa”. Arkady, 1(5), 243-249.

Sobieraj, S. (2017). Wizualność w polskiej poezji międzywojennej. Slavica Tergestina, 19, 80-104. https://www.openstarts.units.it/bitstream/10077/20378/1/SlavicaTer_19_2017_2_Sobieraj.pdf.

Szablowska, A. (2005). Tadeusz Gronowski. Sztuka plakatu i reklamy. Warszawa: Instytut Sztuki Polskiej Akademii Nauk.

Warda, M. (2017). Jan Lewitt, Jerzy Him. W: J. Mrowczyk (Red.), Piękni XX-wieczni. Polscy projektanci graficy (ss. 104-111). Kraków: 2+3D.

Zdrenka, M. (2012, 1 sierpnia). Historia Polskiego Projektowania (1): Atelier graficzne Mewa. https://www.signs.pl/atelier-graficzne-mewa,16263, artykul.html.

Zdrenka, M. (2013a, 13 stycznia). Historia Polskiego Projektowania (2): Atelier Reklamy Artystycznej Plakat. https://www.signs.pl/historia-polskiego-projektowania-\%282\%29\%3A-atelier-re klamy-artystycznej-plakat,17678,artykul.html. 
Zdrenka, M. (2013b, 14 lutego). Historia Polskiego Projektowania (3): Lewitt i Him to szczęśliwe połaczenie. https://www.signs.pl/historia-polskiego-projektowania-\%283\%29\%3A-lewitt-i -him-to-szczesliwe-polaczenie, 17961, artykul.html.

Zdrenka, M. (2013c, 12 marca). Historia Polskiego Projektowania (4): Biuro Reklama-Mechano. https://www.signs.pl/historia-polskiego-projektowania-\%284\%29\%3A-biuro-reklama-me chano, 18185, artykul.html.

Zdrenka, M. (2013d, 15 kwietnia). Historia Polskiego Projektowania (5): Kreatywne duety z Warszawskiej Politechniki. https://www.signs.pl/historia-polskiego-projektowania-\%285\%29\% 3A-kreatywne-duety-z-warszawskiej-politechniki,18456,artykul.html.

Zdrenka, M. (2013e, 6 maja). Historia Polskiego Projektowania (6): Atelier Girs-Barcz. https://www. signs.pl/historia-polskiego-projektowania-\%286\%29\%3A-atelier-girs---barcz,18622, artykul. html.

Zdrenka, M. (2014, 4 sierpnia). Historia Polskiego Projektowania (8): Duet projektantów. https:// www.signs.pl/historia-polskiego-projektowania-\%288\%29\%3A-duet-projektantow, 223 26, artykul.html.

JAN KACZOROWSKI

\section{ARTISTIC PARTNERSHIPS IN THE POLISH PUBLISHING AND ADVERTISING INDUSTRIES IN THE FIRST HALF OF THE 2OTH CENTURY}

\section{Summary}

The formation of various types of artistic partnerships was a common practice among practititioners of commercial art in the interwar period. This phenomenon has been previously discussed by researchers, but it has not received any in depth research treatment thus far. This paper is an attempt at a more synthetic discussion of the issue, its scale, sources and effects. Based on a review of a large selection of commercial art, and on analysis of sources and informational publications, an expansive presentation has been created, of various artistic partnerships active in the first half of the 20th century. On the basis of the formally acknowledged traits, legacy, internal structure and other functional characteristics, the artistic partnerships discussed were divided into three groups: temporary collaborations, artistic cooperatives, and artistic and graphic studios.

A chronology of such artistic corporations is presented, which clearly shows an increasing tendency to to form such organisations throughout the 1920s to the apex of this art form's popularity, which took place in the 1930s. It is shown that this trend was arrested by the outbreak of war, but it continued to influence similar artistic collaborations, which were initiated immediately after the war, and also in later periods.

The article also highlights numerous problems experienced by such artistic partnerships, which should be the subject of further study. The data which has been gathered about artistic partnerships, while incomplete, has been presented in the form of a table as a basis for further research in the future.

KEY WORDS: applied arts in Poland between 1900-1950, artists partnerships, artistic cooperation, design studios 